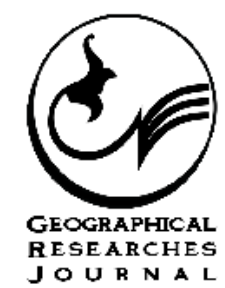

\title{
Explanation of electoral Competition Tribe-based in the Framework of the Model of Core-Periphery Case Study: Eighth, Ninth and Tenth Elections in the Mamasani Constituency
}

\section{ART ICLE INFO}

\section{Article Type}

Original Research

\section{Authors}

Kaviyan Rad M.* PhD,

Hosseini MH. ${ }^{1} M A$

Sadeghi V. ${ }^{2} M A$

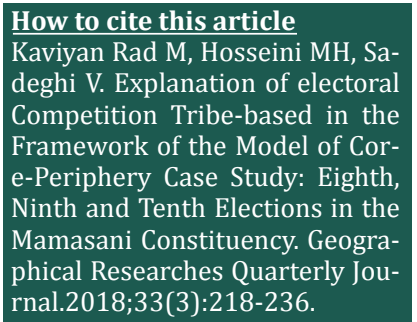

*Department of Political Geography at univercity of kharazmi, Tehran, Iran

${ }^{1}$ Department of International Relations at Allameh Tabataba'i University, Tehran, Iran

${ }^{2}$ Department of political geography at Ferdowsi University of Mashhad, Mashhad, Iran

\section{*Correspondence}

Address: NO. 43, Shahid Mofateh Street, Tehran, Iran. Postal Code: 1491115719

Phone: -

Fax: -

kaviani75@yahoo.com

\section{Article History}

Received: May 06, 2018

Accepted: August 05, 2018

ePublished: December 09, 2018

\section{A B S T R A C T}

Introduction and Background The model of core-periphery is evidence of unequal relationships between societies, regions, classes, and different social strata that are very effective in shaping the behavior of actors. This issue is noticeable in areas such as Mamasani County that social structure has a tribal nature. So that in each tribe, some of the populous ancestry and villages are able to influence other geographic areas around them in social and political spheres. In the Mamasani constituency, the electoral behavior of residents in the context of the geographical environment, spatial and kinship feelings, due to the role of the major geographical cores (wheels) and peripheral affiliates (blacks), can trigger emotional behavior in political choices. In this regard, the role creating a model of the core of the periphery in the political sphere, such as the parliamentary elections, affects the participatory model of the inhabitants of this city, and the field of the formation and construction of the Pratori Society

Aims The present study is based on the assumption that there is a significant relationship between the center of periphery and tribalism, and this structure is important through the geographical area and the division of the areas under the control of the clans into the most important and important part of the old times, and their division of labor, especially during the election in the current era, while creating a labor society, it leads to an increase in tribal tendencies in social and political arenas.

Methodology The research method has a descriptive-analytical nature and the required data are collected through library, documentary and field studies (observation).

Conclusion The findings of the research showed that some of the urban regions and high-impact villages (as centers) effect the patterns of behavior of residents of other peripheral regions and the ability to shape emotional behavior in the pratori community, finally, tribalism in the social and political arenas. Keywords Core-Periphery Model; Pratori Society; Tribalism; Elections and Mamasani Constituency

\section{I T A T I O N L I N K S}

[Ahmadipour \& Karimi; 2013] Patholigy of election in Iran, case study: Islamic consulative ...; [Bashirie; 2001] Democracy lessons for ...; [Bashirie; 2011] The history of Marxist ...; [Dadashpour, et al.; 2011] Review and analysis of development trends and spatial ...; [Dehghan Naserabadi; 2006] The story and secrets of the Sandogh ...; [Delavari; 2008] The study of the roots of violence and political ...; [Deputy of Planning and Employment of Fars Province; 2014] Statistical Yearbook of Mamassani County ...; [Eghtedari; 1996] Khouzestan and Kohgiloie and ...; [Estes; 2006] Where the votes are: The electoral geography of the coming ...; [Governorate of Mamssani; 2007] Report of the outcome of the eighth islamic parliamentary election ...; [Governorate of Mamssani; 2011] Report of the outcome of the ninth islamic parliamentary election ...; [Governorate of Mamssani; 2015, 2016] Report of the outcome of the eighth islamic parliamentary election ...; [Hafeznia \& Kaviani Rad; 2014] Philosophy of political ...; [Heywood; 2016] Politics ...; [Huntington; 1991] The political system in the societies ...; [Jaafarinejad, et al.; 2011] Analysis of the voting ...; [Jones; 2007] An introduction to political ...; [Kaviani Rad; 2013] Election geography, with emphasis on presidential ...; [Kaviani Rad \& Gharahbeygi; 2017] Election geography, fundations, concepts ...; [Mirzaeitabar, et al.; 2015] Explaining the relationship between political ...; [Niakoui; 2014] Sociology of political disputes ...; [Patti; 2006] Electoral geography for ...; [Political-Security Birth Certificate; 2011] Governorate of Nourabad Mamassani ...; [Rahnavard \& Mahdavirad; 2010] Management of ...; [Rumina \& Sadeghi; 2015] Investigating the effect of tribalism ...; [Saedi; 2011] The principle of rural ...; [Statistical Center of Iran; 2006] Statistical Yearbook, National and provincial ...; [Statistical Center of Iran; 2011] Statistical Yearbook of Fars Province, Population statistics ...; [Veisi; 2016] Concepts and theories of political ... 
Kaviyani Rad M. PhD

Hosseini MH. MA

Sadeghi V. MA

kaviani75@yahoo.com

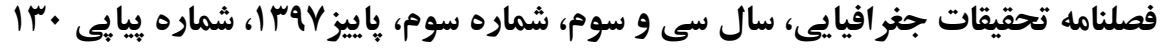

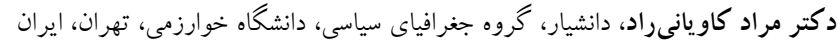

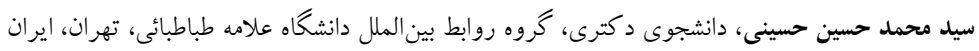

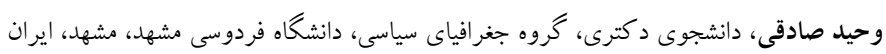

\section{تبيين رقابت انتخاباتى طايفهمور در جار جوب مدل مركز ـ پِيرامون نمونه يُؤهى: انتخابات ادوار هشتمه نهم و دهم در حوزه انتخابيه مَمَسَنى و رستم}

يذيرش نهايى:|rqV/D/If

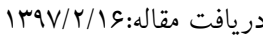

DOI: $10.29252 /$ geores.33.3.218

جكيده

مقدمه: مدل مر كز - ييرامون كواه بر روابط نابرابر ميان جوامع، مناطق، طبقات و اقشار مختلف اجتماعى است كه در شكل-

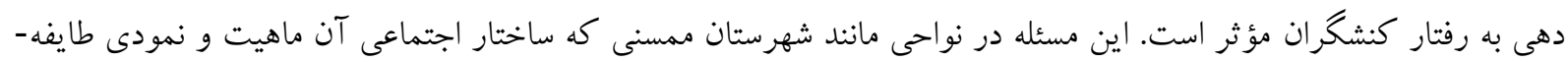

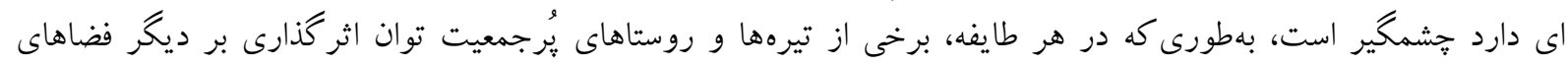
جغرافيايى ييرامون خود در حوزههاى اجتماعى و سياسى رادارند. در اين خارجوب، نواحى كه در كانون هر يكى از قلمرو

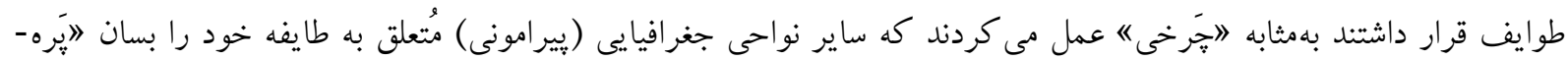

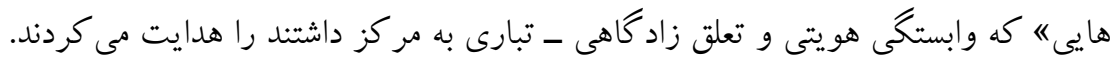
اهداف: اين يزوهش در يى تبيين رقابت انتخاباتى طايفه محور در خارجوب مدل مركز - يّيرامون است. مواد و روشها: يزوهش حاضر كه ماهيتى كاربردى دارد به بررسى و يردازش رابطه سه متغير مدل مركز - بيرامون بهمثابه

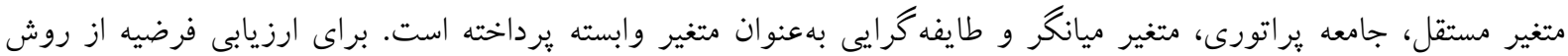

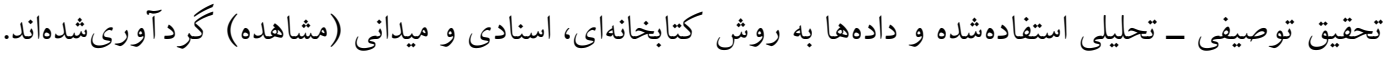
نتيجه گيرى: يافته هاى يزوهش نشان داد كه برخى از نواحى شهرى و روستاهاى متنفذ (بهعنوان مركز)، ألكوى رفتنارى ساكنان

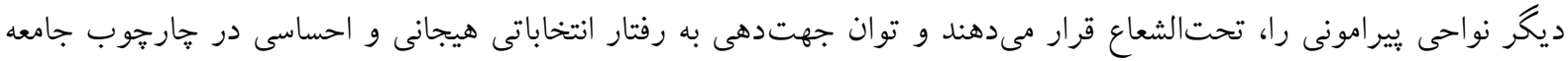

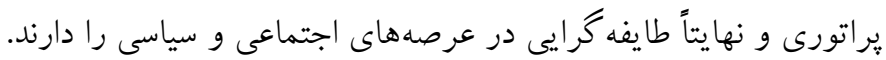

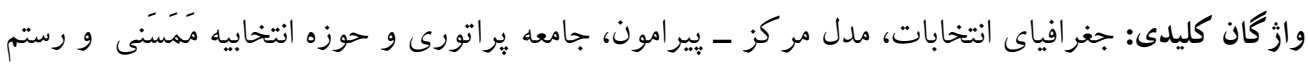

مقدمه

مدل مركز - بيرامون كه در وصف مؤلفههاى سياسى و اقتصادى در كشورهاى توسعهيافته و درحالتوسعه به كار مىرود،

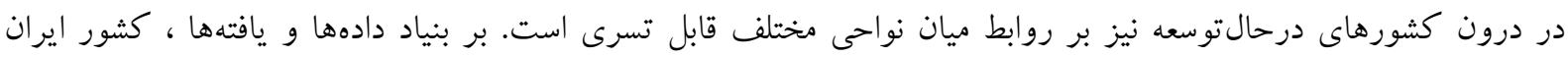

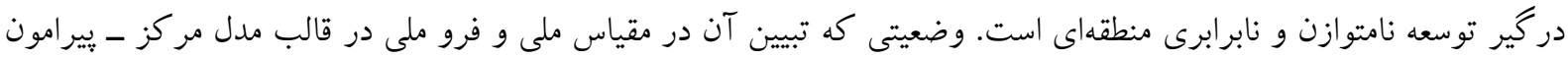
ممكن است. در اين ميان، مدل يادشده براى تبيين نواحى ييرامونى نظير شهرستان ممسنى به كاررفته شده است. دادهها و ديدهها

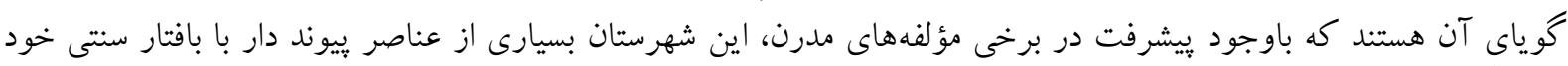

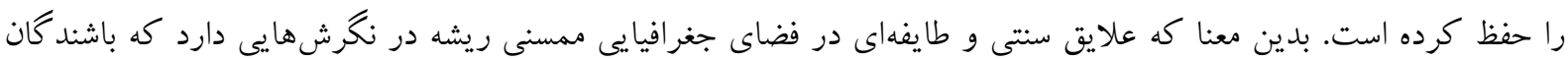


Ir. r. Tr.

ممسنى از كذشتههاى دور (يراكسيس ') به ارث برده و در قالب ساختار مركز - يبيرامون به روابط اجتماعى كنونى ساكنان اين

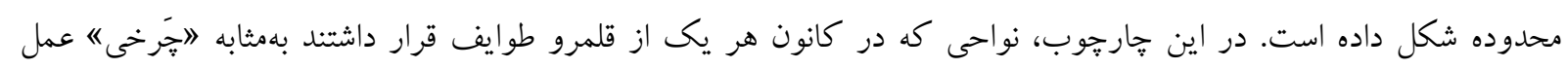

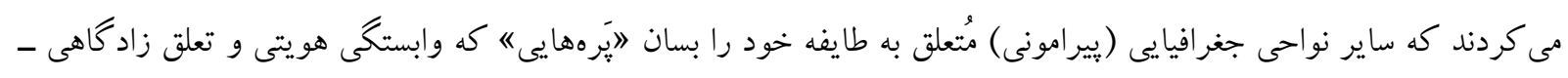

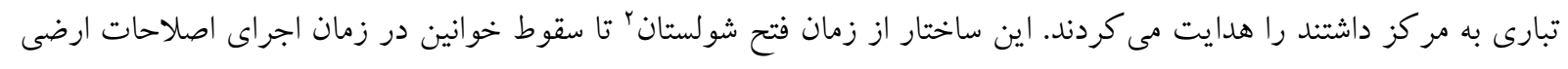

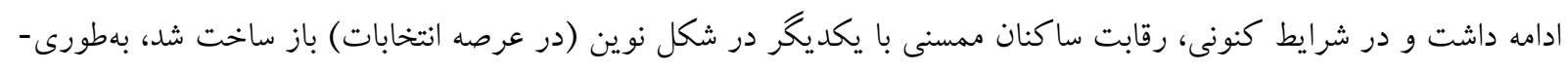

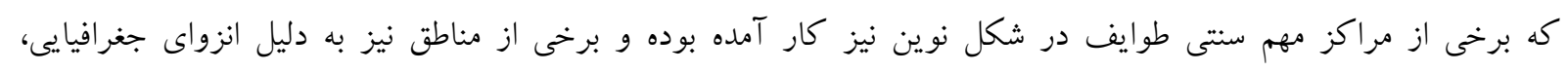

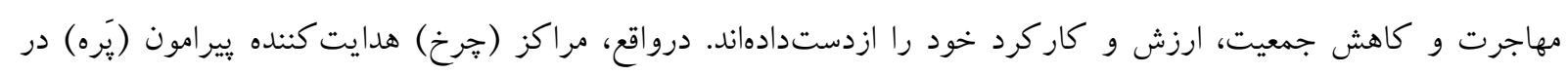

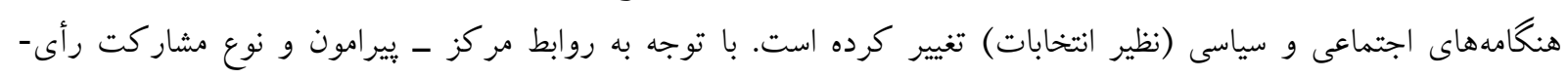

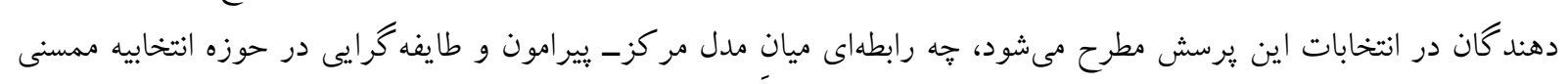

و رستم وجود دارد؟

روش تحقيق

يزووهش حاضر كه ماهيتى كاربردى دارد به بررسى و يردازش رابطه سه متغير مدل مركز - بييرامون بهمثابه متغير مستقل،

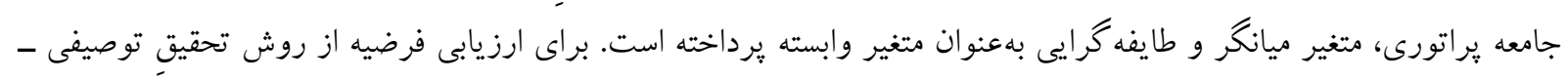

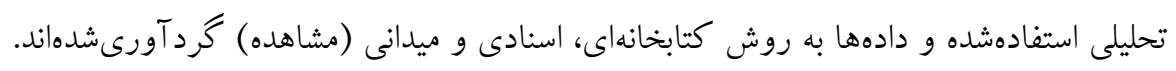

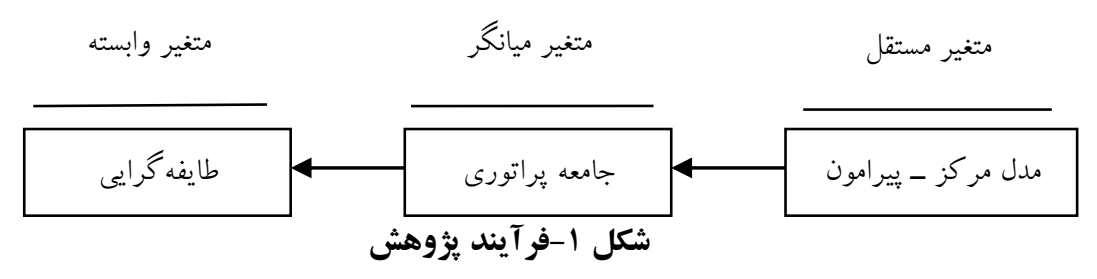

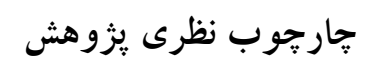

مدل مر كز- بيرامون

انديشمندان مختلفى جستار مركز - بيرامون را مطرح كردهاند كه معروف ترين آنها نظريه امانوئل والرشتاين م كه در دهه

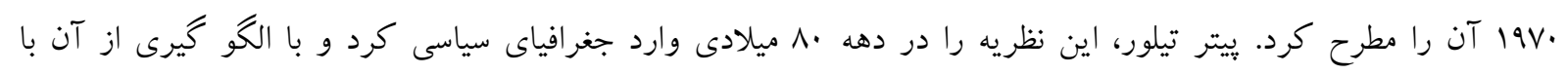

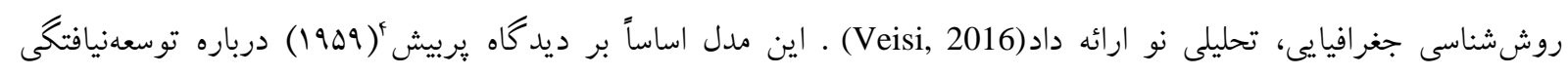

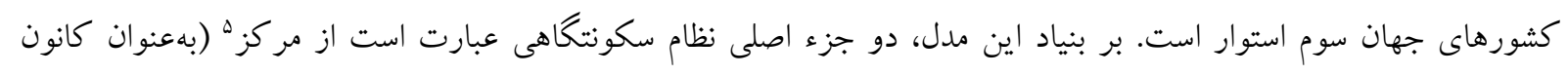

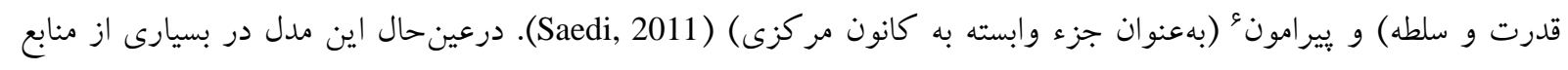

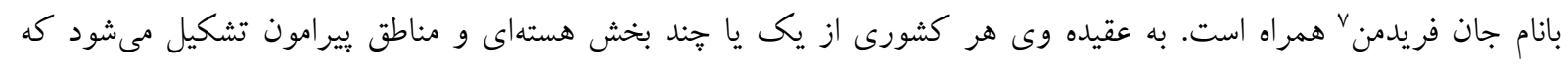

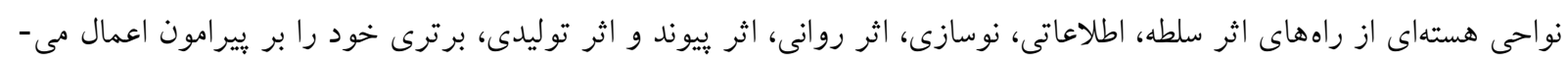

3 Immanuel Maurice Wallerstein

4 R. Prebisch

5 Core

6 Periphery

7 John Friedman 
كند. درنتيجه ساختار فضايى كشور به شكل كاملاً آشكارى به دو بخش متمايز مركز (بهعنوان قدرت و سلطه) و ييرامون (به-

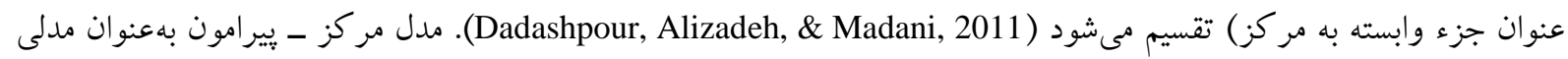

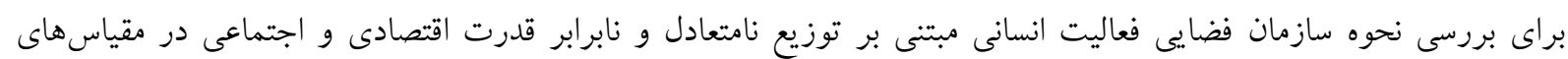

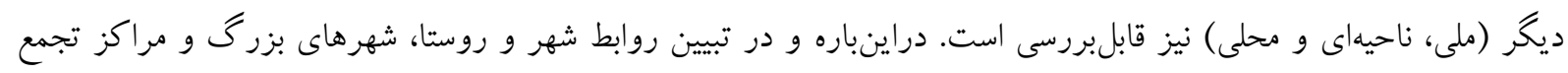

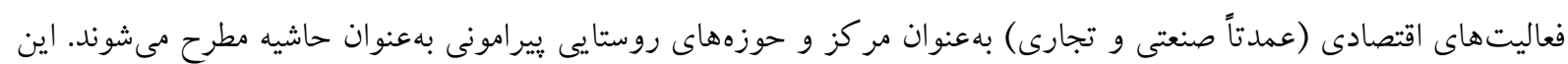

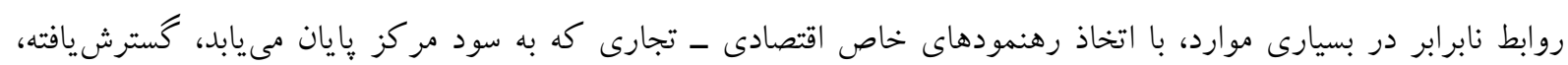

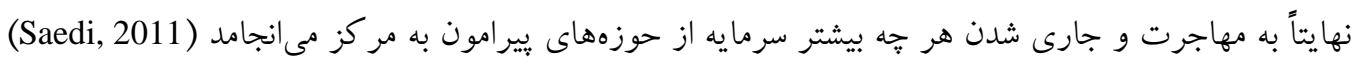
جامعه : براتورى

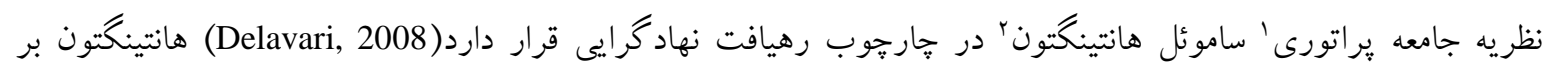

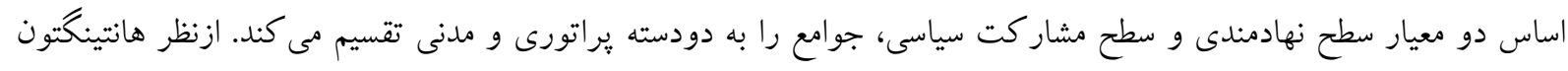

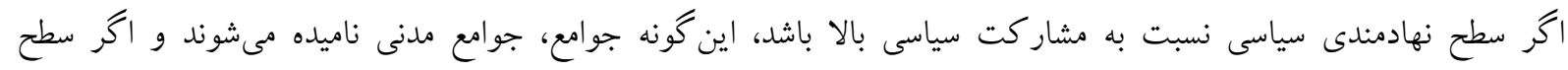

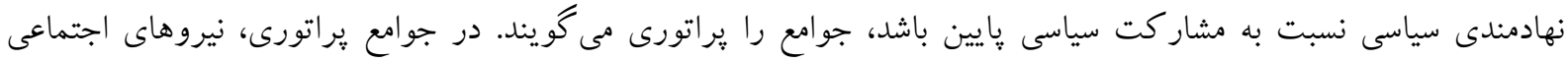

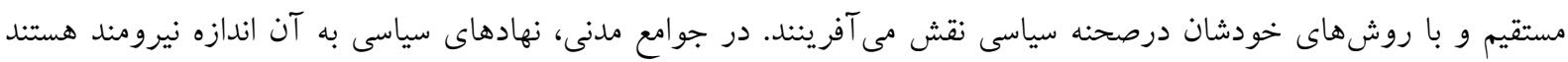

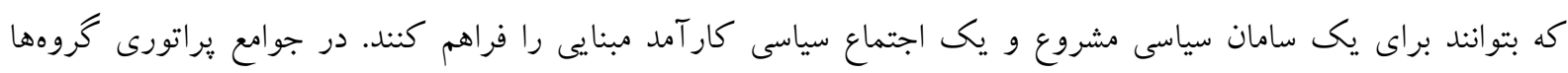

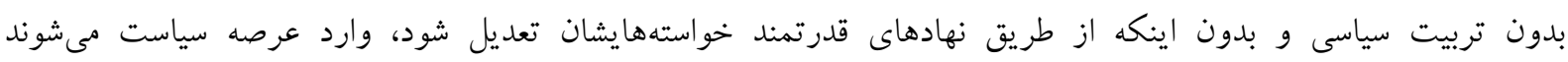

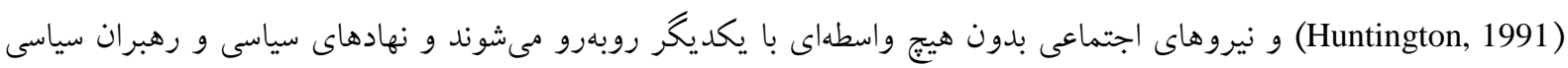
حرفهاى بهعنوان ميانجىهايى مشروع براى تعديل كشمكش بين گروهها به رسميت شناخته نمىشوند (Niakoui, 2014).

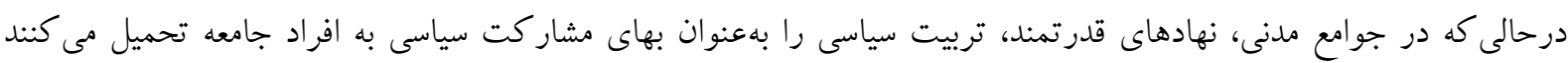

(Huntington, 1991)

طايفه گرايى

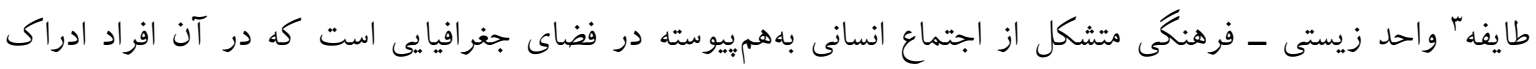

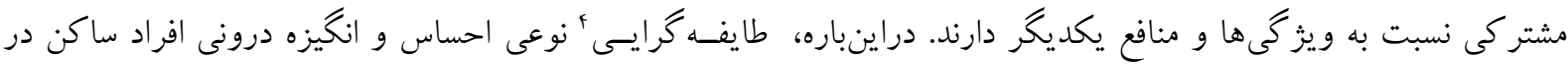

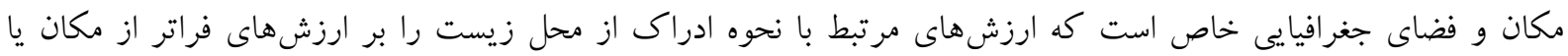

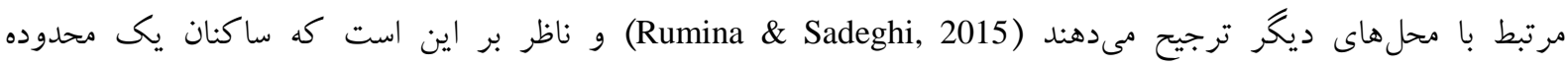

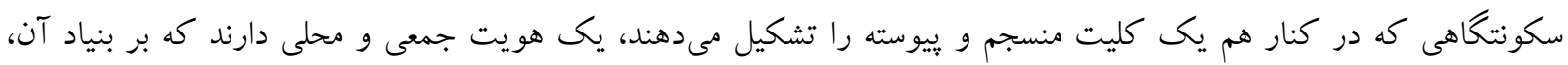

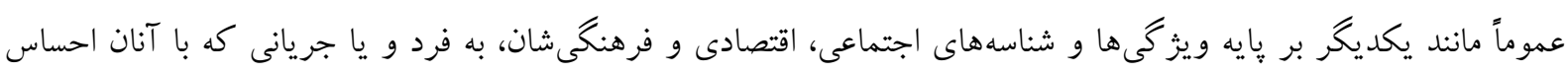

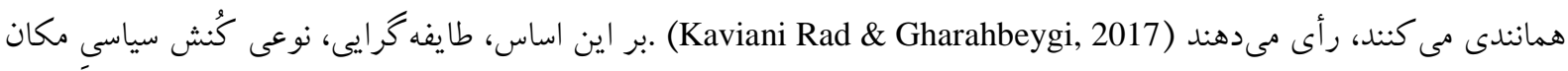

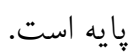

1 Praetor community

2 Samuel Huntington

3 Tribe

4 Tribalism 


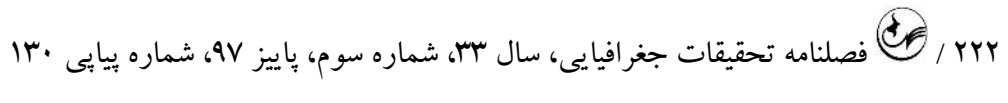

جغر افياى انتخابات

انتخابات'، روشنترين فرصت رسمى براى تأثير كذارى بر فرايند سياسى (Heywood, 2016) ، مؤثرترين مجراى عملى شدن دمو كراسى (Rahnavard \& Mahdavirad, 2010) ، مهم ترين وسيله انعكاس افكار عمومى (Bashirie, 2001)، قوى ترين كُنش سياسى مدنى و تبلور عينى مشاركت مردم (Jaafarinejad, Babanasab, \& Shahriar Rabiei, 2011) و و شيوه (B.

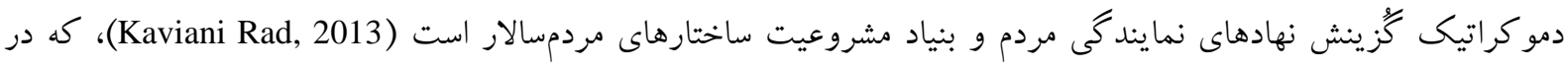

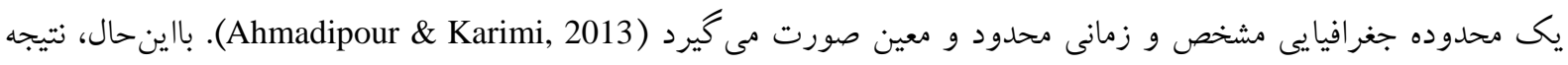

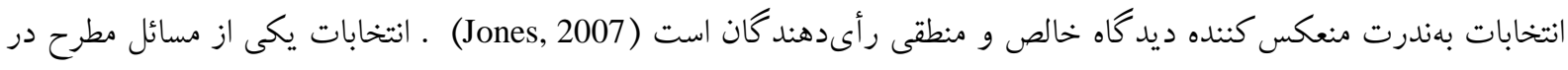

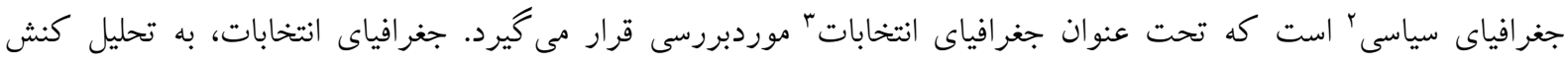

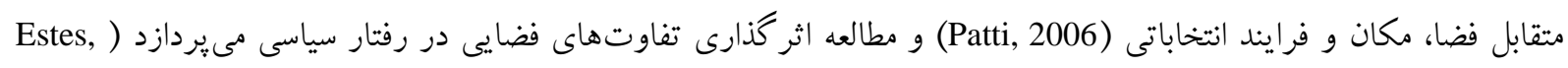

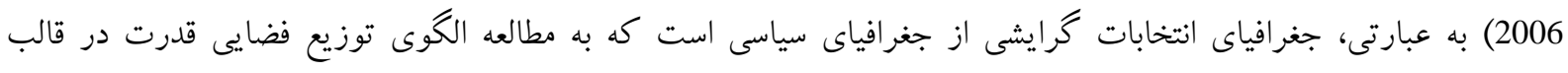

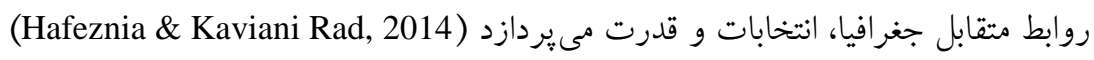

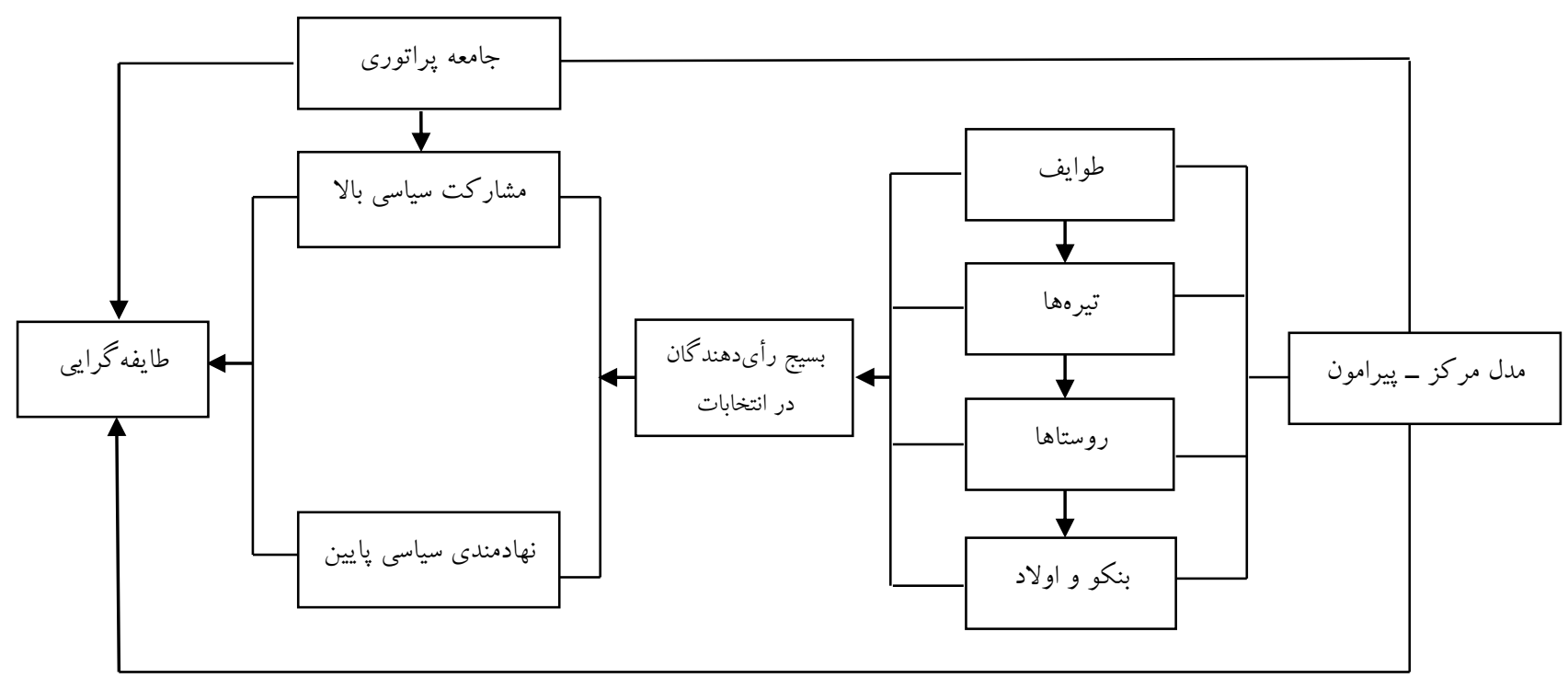

\section{شكل r- الكوى نظرى تحقيق}

تبيين روابط بين مفاهيم تحقيق بر بنياد الكوى نظرى فوق بدين شرح است كه مدل مركز - بيرامون دربر گيرنده جهار بخشِ

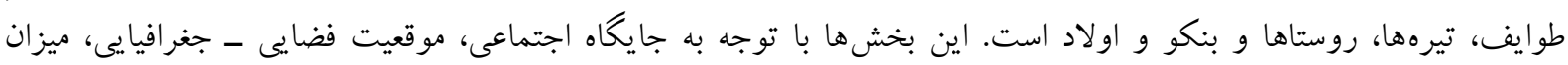

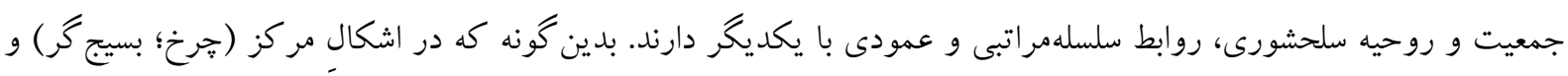

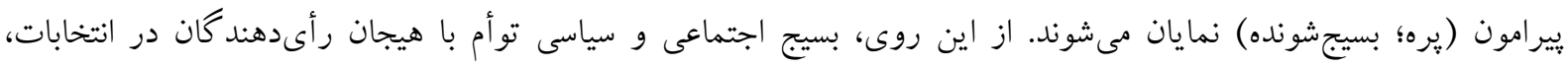

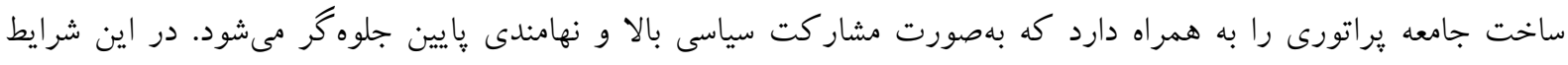

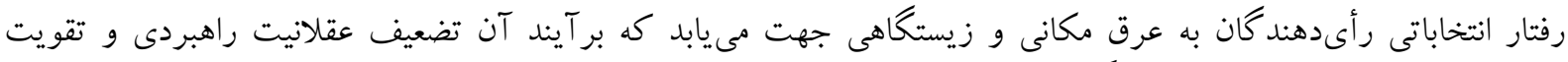

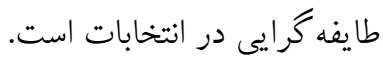




\section{محيطشناسى تحقيق}

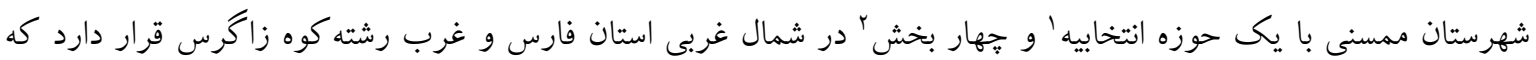

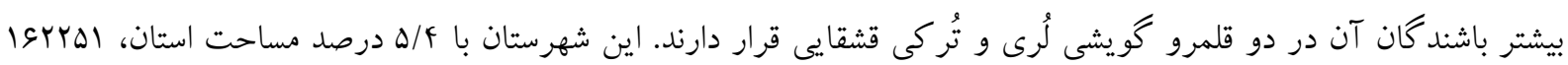

نفر جمعيت دارد (Deputy of Planning and Employment of Fars Province, 2014)

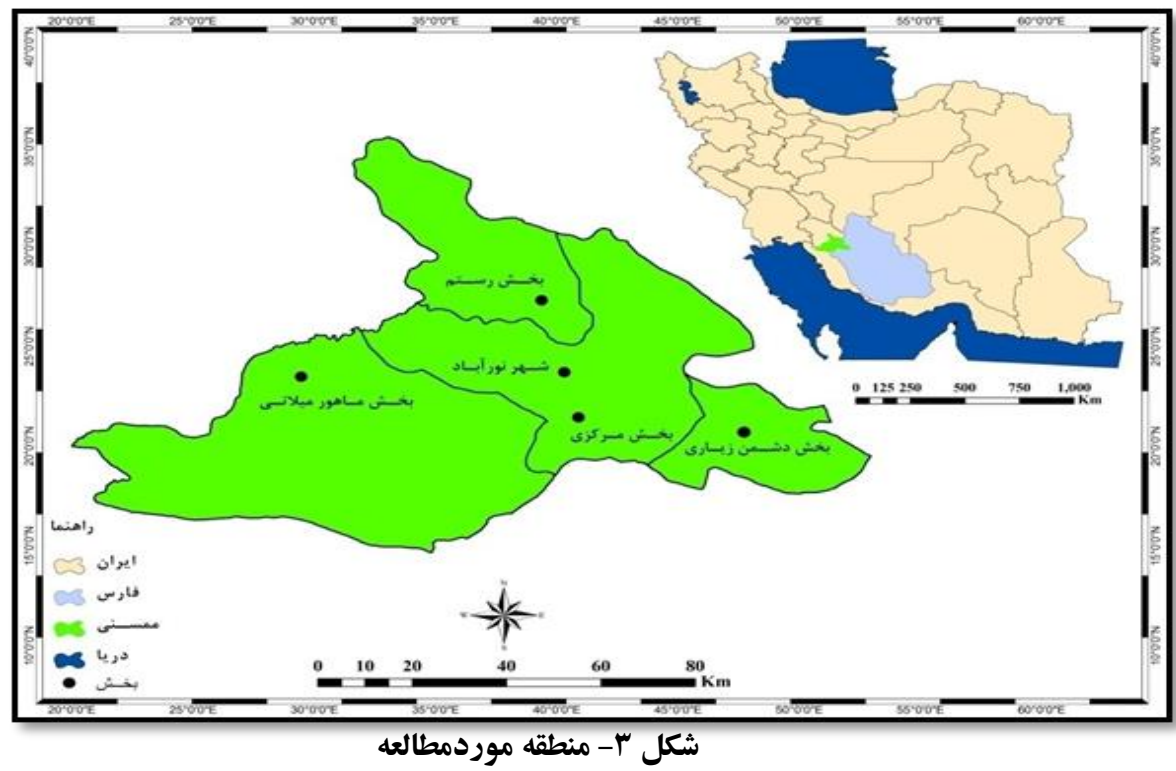

مدل مركز - يِيرامون در جوامع ايلى و طايفهاى ممسنى به دليل اهميت فضاهاى جغرافيايى متُعلق به طوايف، صرفاً درد

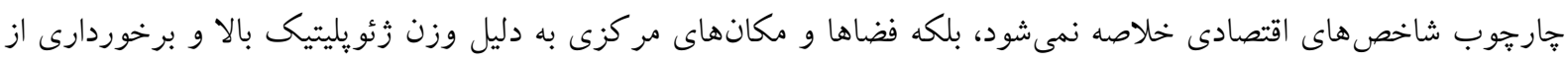

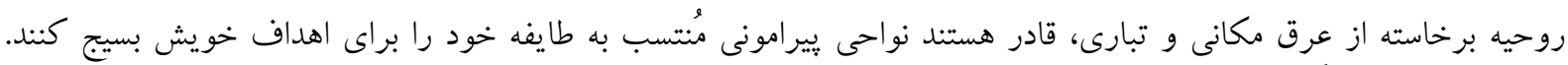

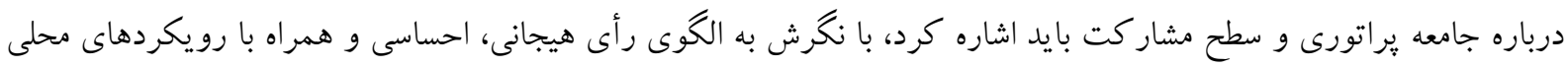

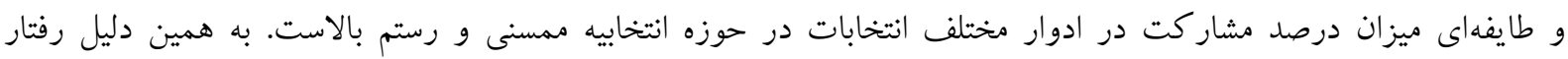

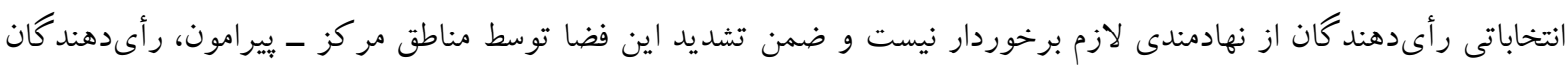

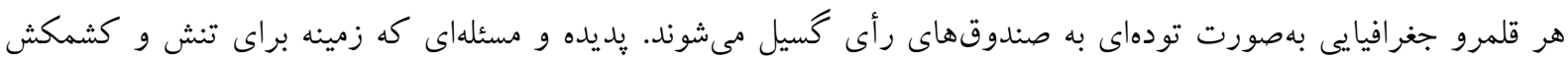
طايفهاى در انتخابات را فراهم مى كند.

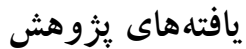

\section{يراكسيس و جامعهشناختى الكوى مر كز - ييرامون}

يراكسيس به معناى انجام دادن، تمرين كردن و استفاده عملى از امرى يا جيزى است. اين حوزه (يراكسيس) يا نيروهاى توليد، حوزه حر كت هستند و در جامعه نقش هدايت امور رادارند) Bashirie, 2011) يراكسيس در ممسنى بستر يِيشرفت و

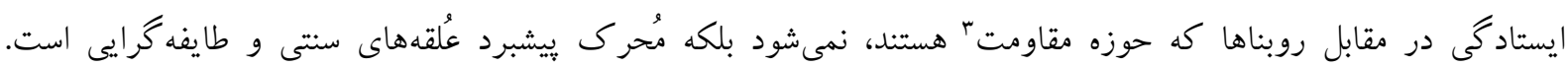


Ir. TrF , TrF يافته هاى موجود نشان مى دهد كه ساختار فرهنكى، اجتماعى و سياسى ممسنى تا زمان سقوط خوانين بيجيده و متأثر از اصل

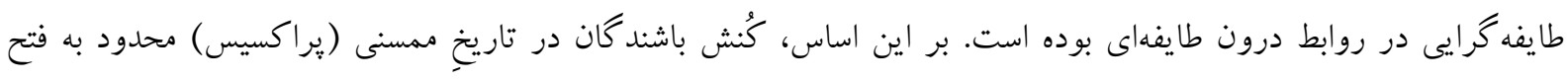

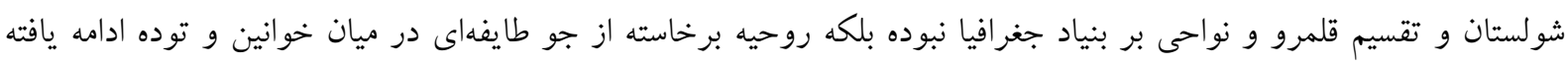

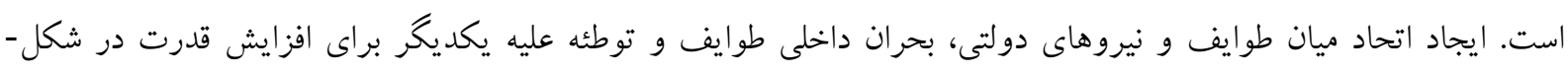

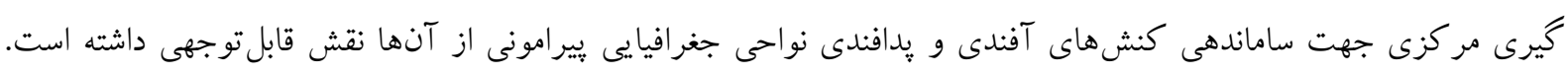

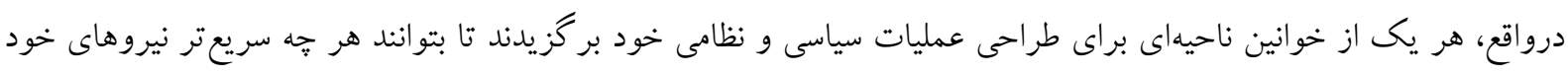

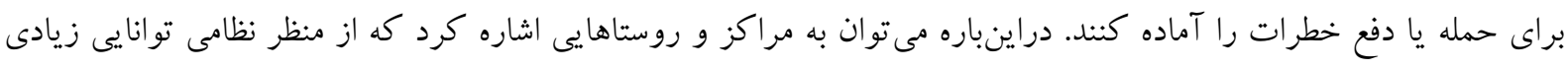

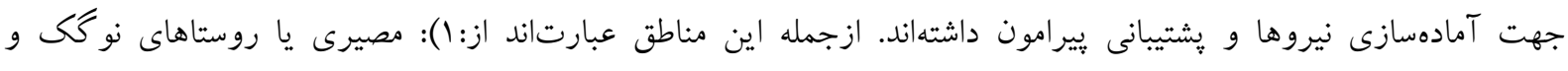

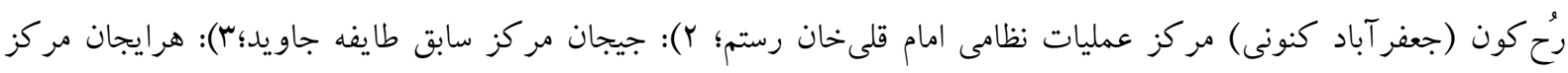

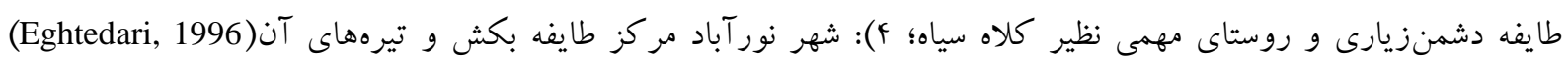

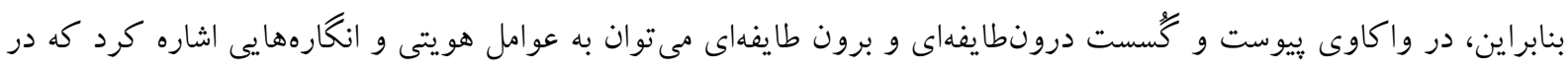

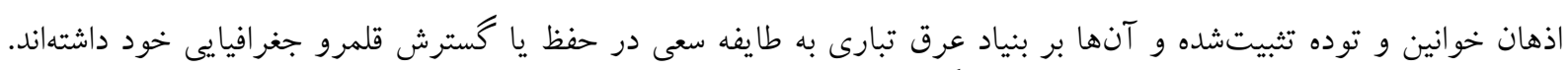

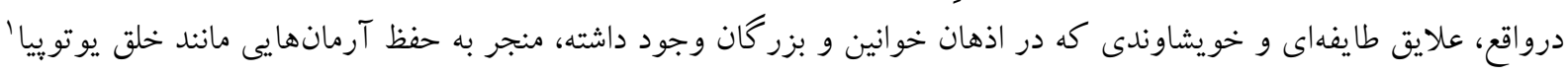

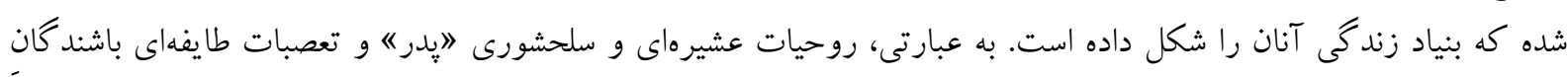

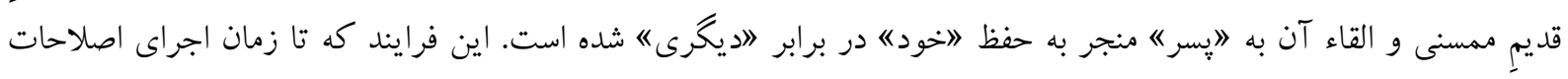

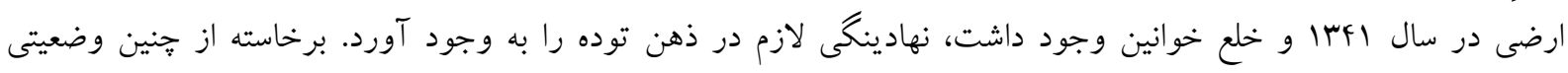

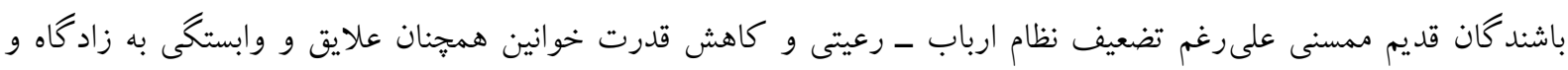

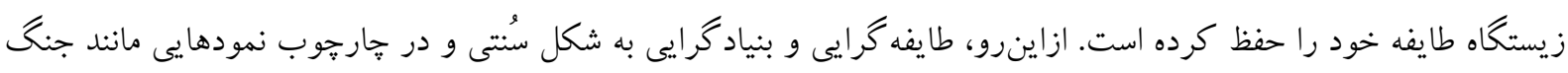

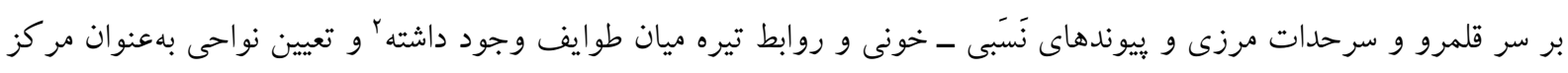

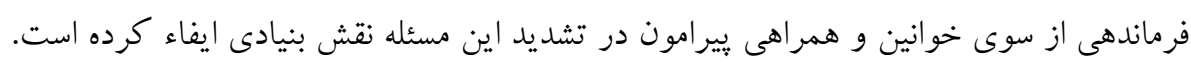

\section{كارويزه مر كز- يِيرامون پِ از خلع خوانين}

مدل مركز - يبيرامون در ممسنى گوياى وجود مراكز مهم جغرافيايى و راهبردى در هر طايفه است كه قادر هستند، فضاهاى

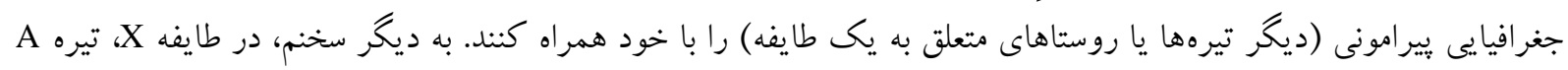

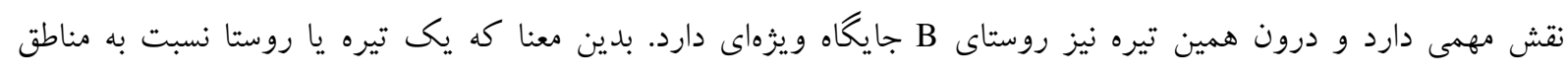

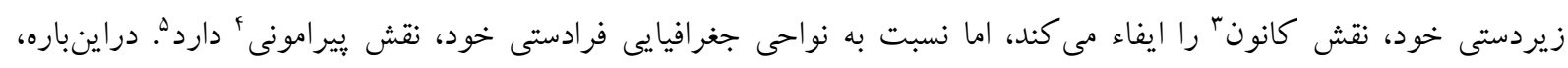

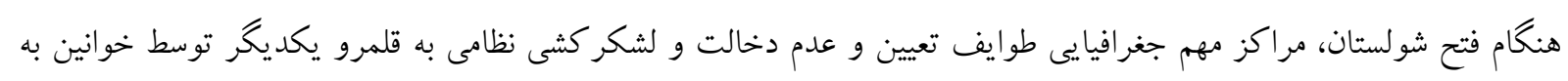

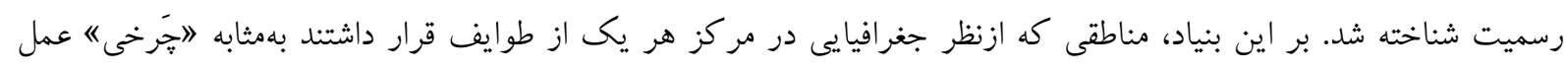

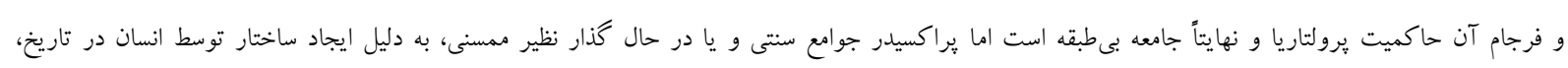

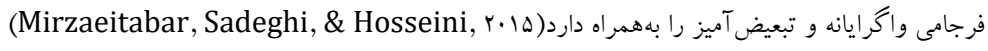

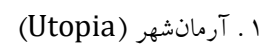

3 Core

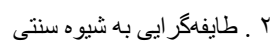

4 Periphery

ه . در تقسيمبندى مركز - يیيرامون، عواملى نظير موقعيت جغرافيايى تيرهها و روستاها، ميزان جمعيت، سابقه تاريخى در تحولات سياسى ممسنى و ميزان تأثير كذارى 
مى كردند كه ديخر نواحى بيرامونى متعلق به طايفه خود را مانند "بَرَههايى" كه وابستىى هويتى و عرق تبارى به مركز داشتند

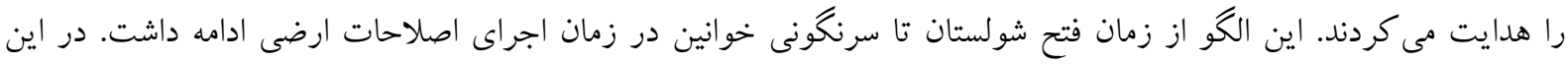

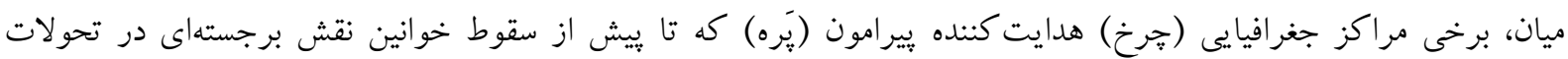

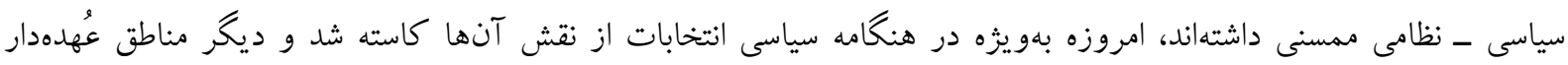

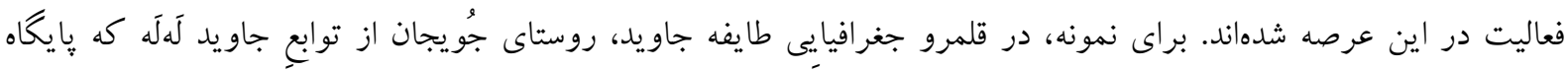

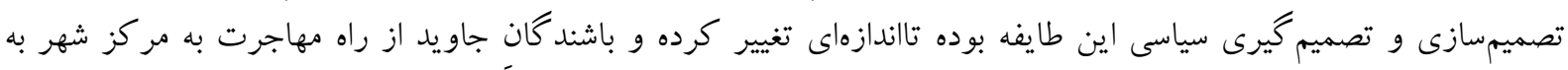

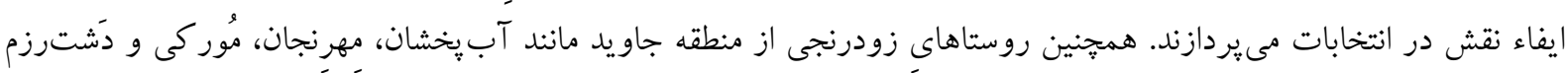

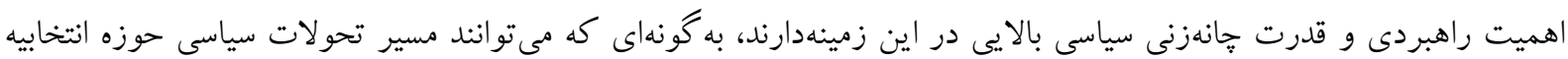
را متحول كنند. دراينباره، دوره هشتم انتخابات (مجلس) كه رقابت اصلى ميان على احمدى از طايفه جاويد (نماينده وقت) و

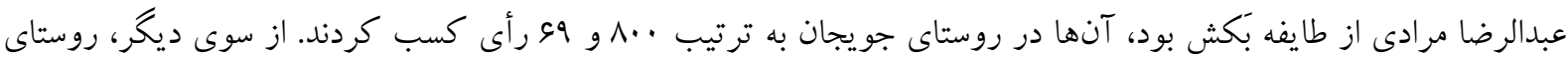

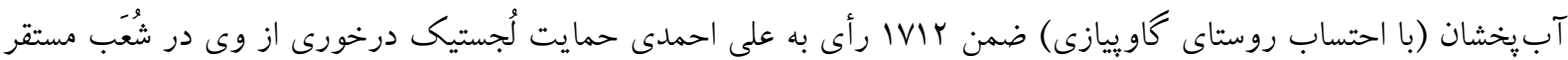

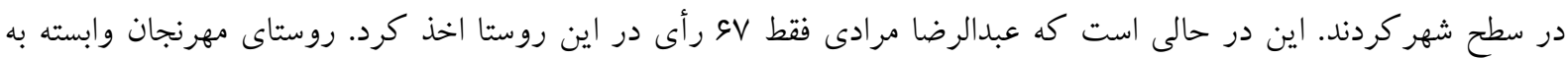

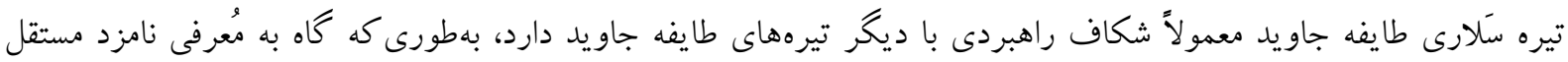

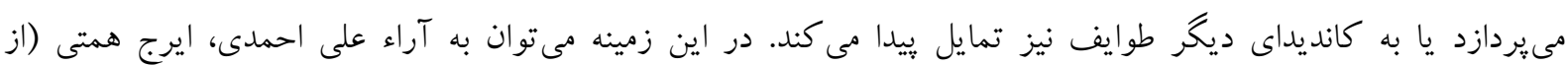

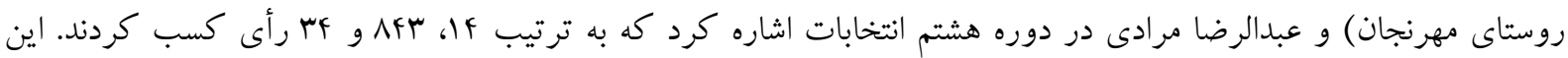

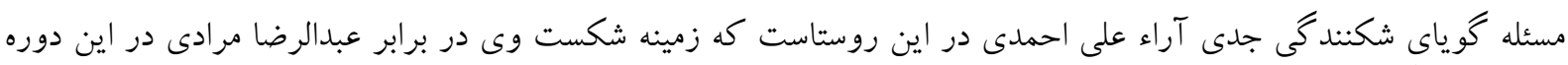

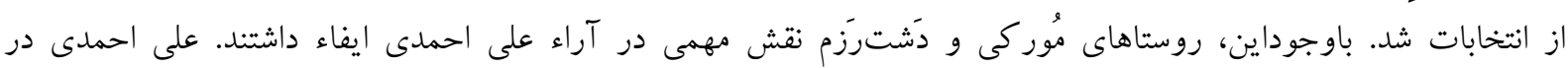

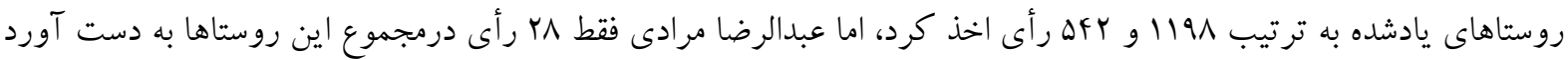

(Governorate of Mamssani, 2007) نقش روستاهاى يادشده بهعنوان مناطق مركزى طايفه جاويد در دوره نهم انتخابات نيز مشهود است. در اين دوره هماوردى (طان

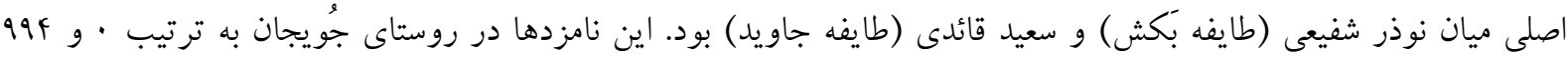

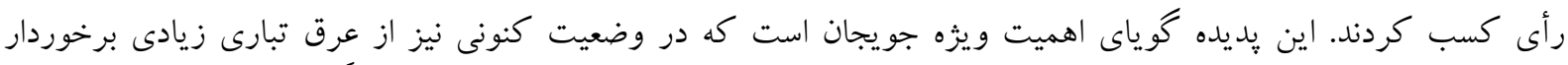

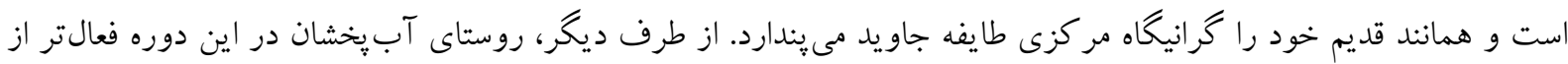
هميشه ظاهر شد؛ خراكه نامزد طايفه جاويد از اين روستا برخاسته بود. ازاينرو، آنها نهتنها سلوال رأى (با احتساب روستاى

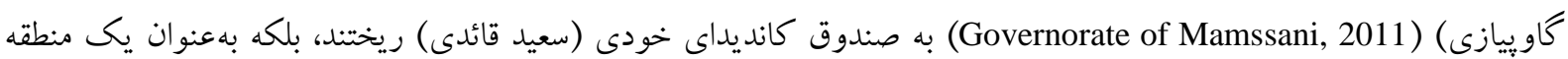

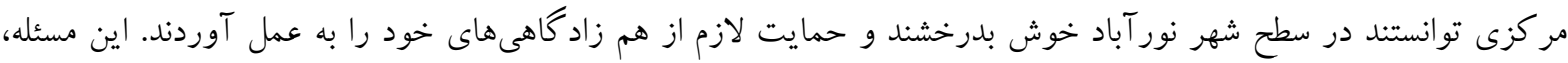

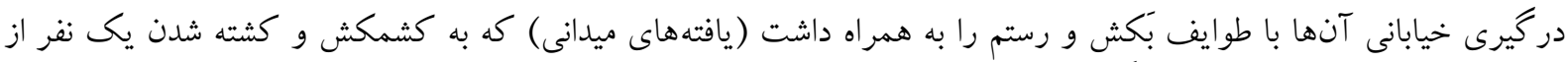

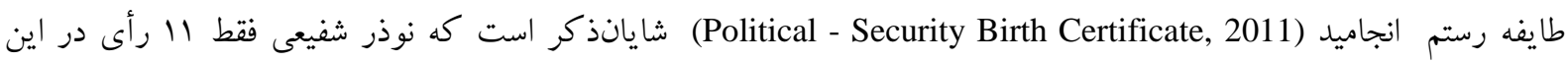

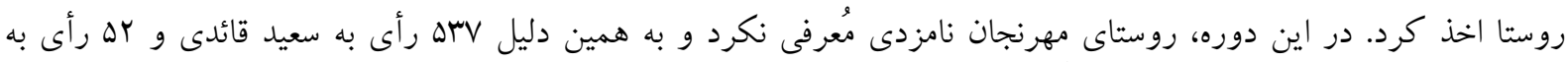

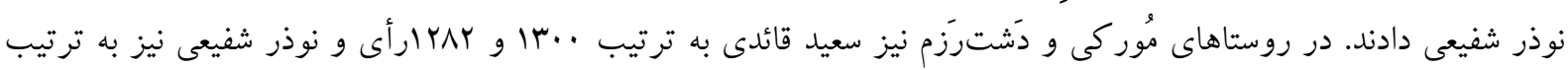

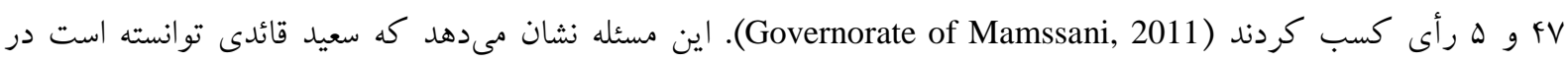
روستاهاى مهم مُوركى و دشترزم نسبت به رقيب بافاصله زيادى ييشتاز باشد.

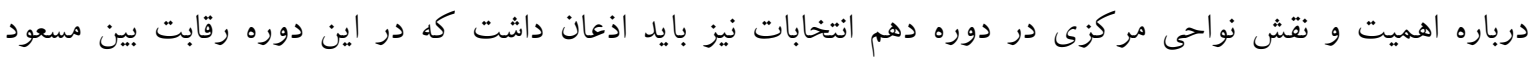

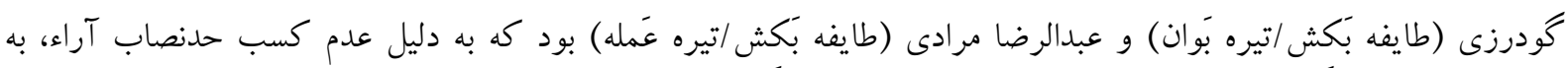




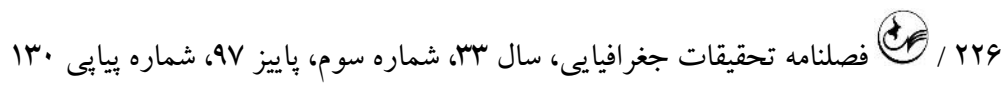
مرحله دوم راه يافتند. شايان توجه است كه جُويجان بهعنوان كانون جغرافيايى ـ سياسى سابق قلمرو جاويد به دليل شكاف سنتى

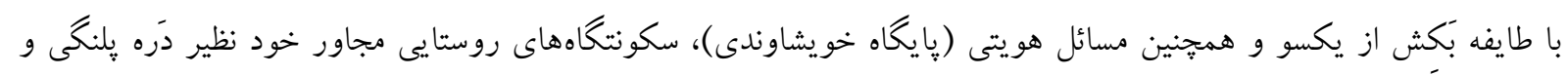

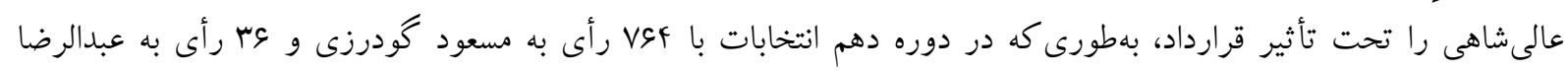

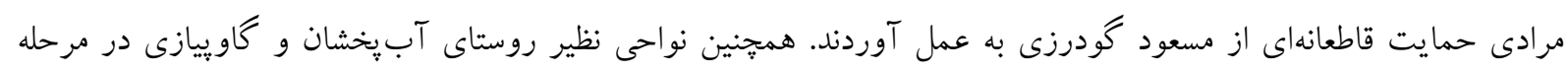

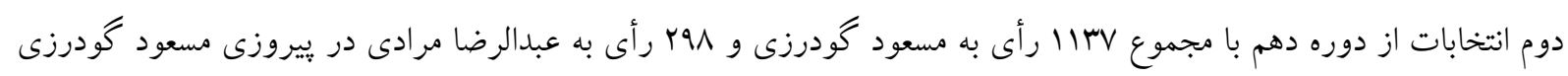

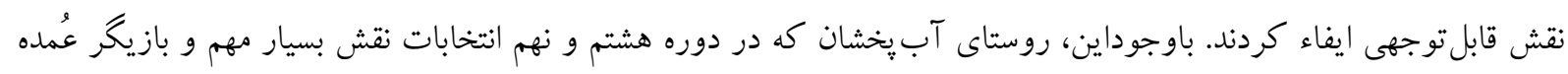

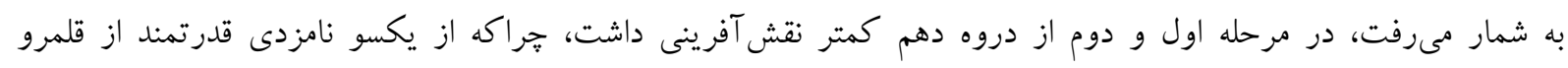

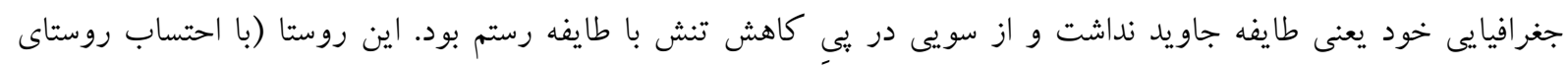

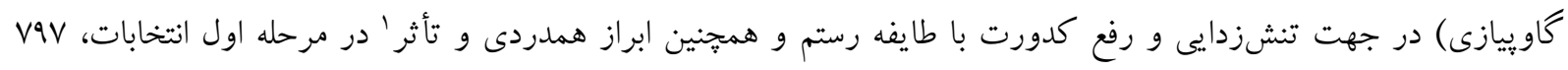

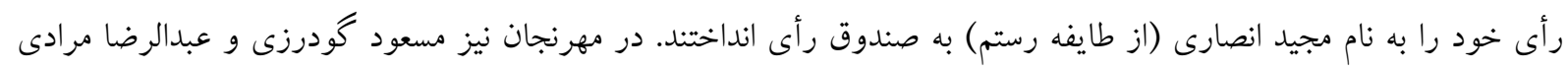

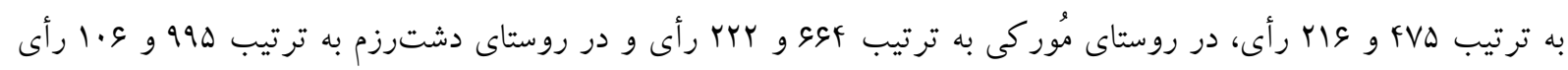

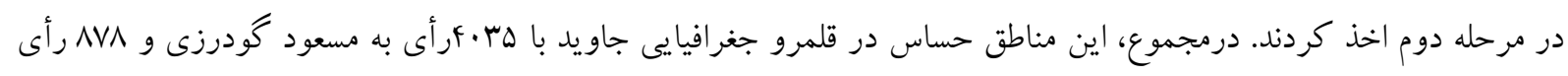

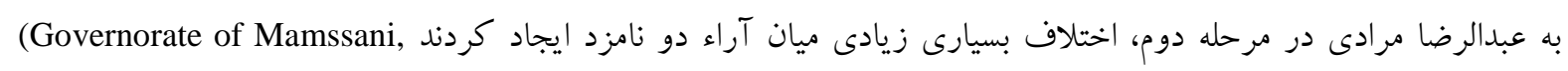

2015, 2016)

در قلمرو جغرافيايى بكش، تيرههايى نظير عَمَكه و بابرسالار تا يُش از سرنكونى خوانين به دليل ستيز با يكديخر يا با ديخر

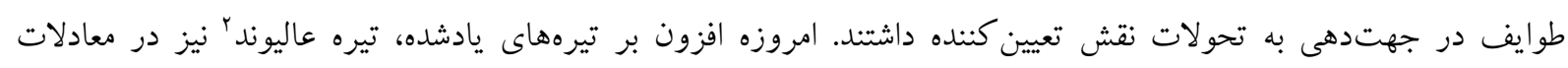

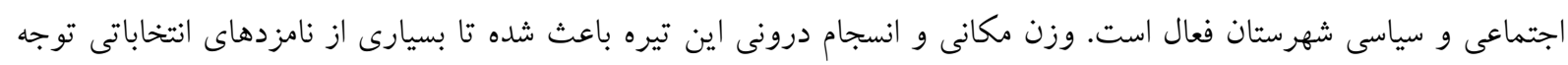

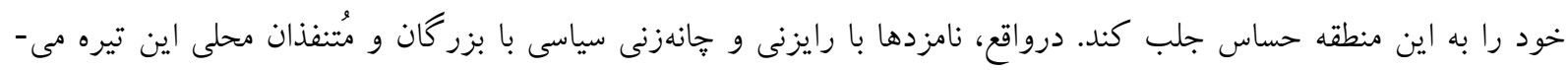

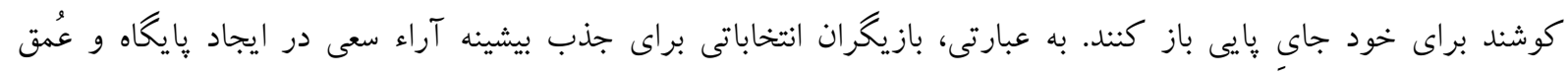

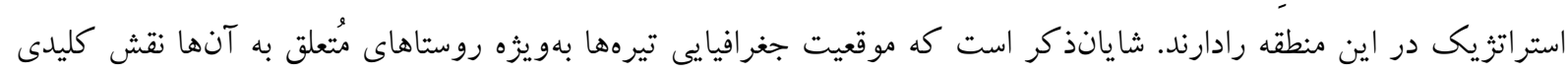

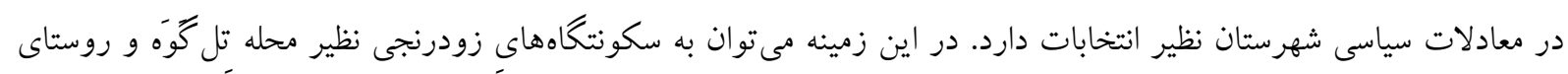

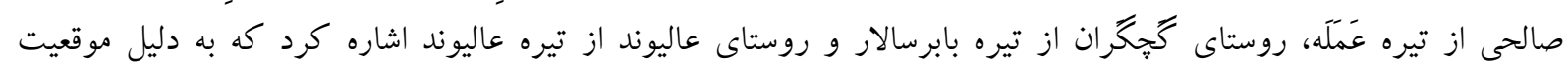

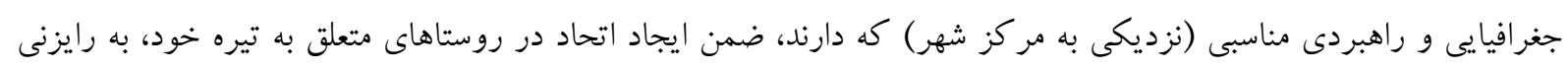

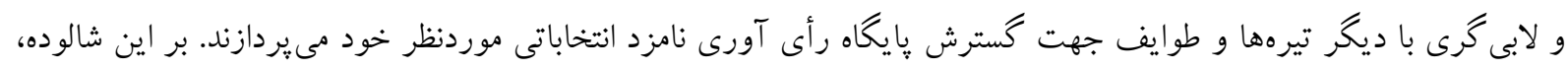

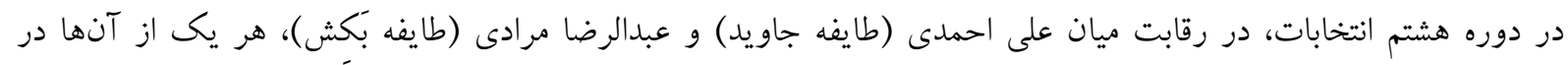

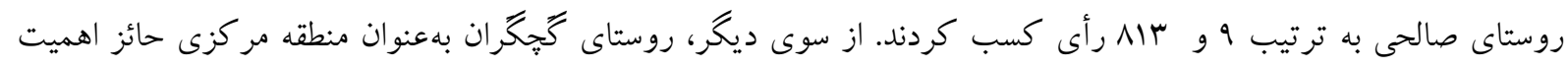

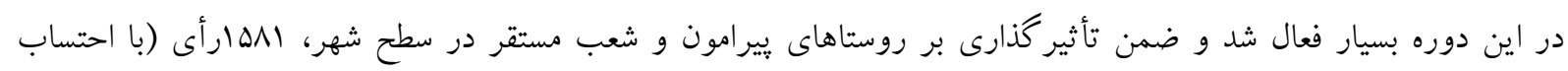

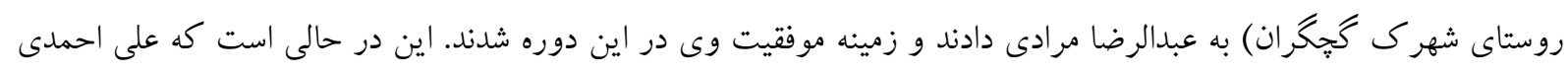

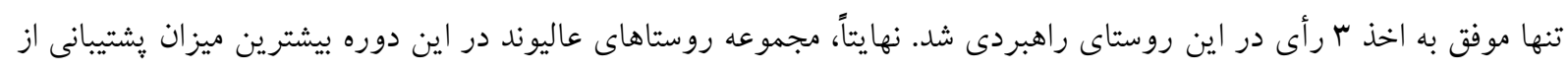

الا در انتخابات دوره نهم يكى از ساكنان طايفه رستم در روز انتخابات مورد اصابت كلوله قرار گرفت و كشته شد) Political - Security Birth

(Certificate, $r \cdot 11$

با ـ تيره عاليوند در ابتداى استقرار ايل ممسنى و در زمان ميرىخان به دليل روابط سبّى با خاندان زند قدرت بسيار زيادى داشت، ولى پيس از به قدرت رسيدن ولى- 
عبدالرضا مرادى را به عمل آورد، بهطورى كه اين نامزد توانست الهو رأى در اين مجموعه روستا به دست آورد اما على احمدى كائ

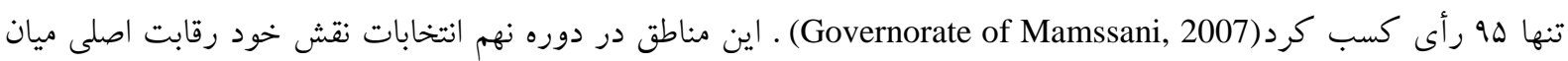

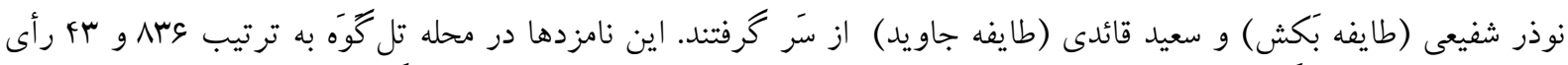

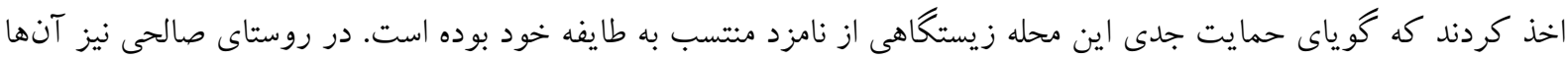

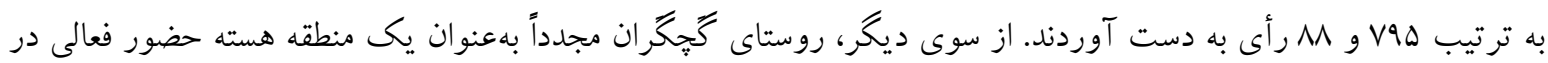

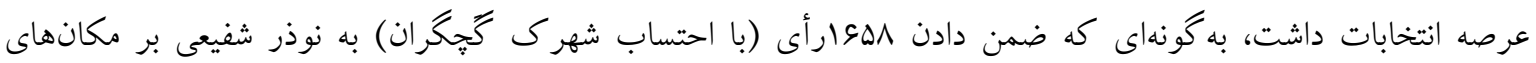

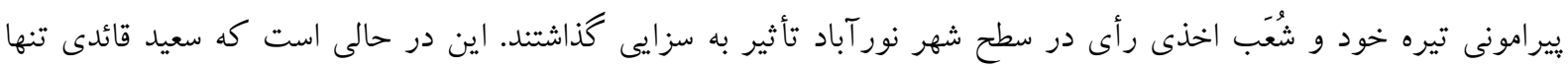

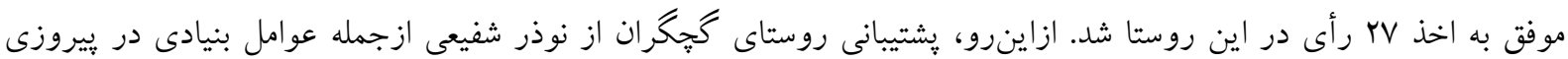

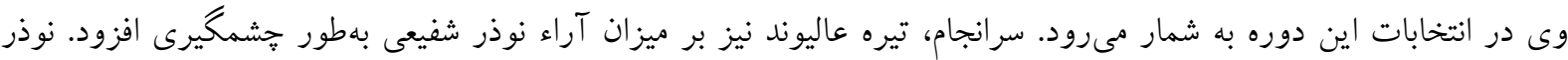

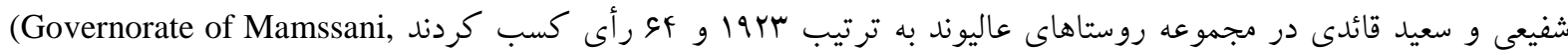

درباره دوره دهم انتخابات نيز هرجند هر يكى از مناطق مر كزى در انتخابات نقش آفرينى ويزه خود را داشتهاند، اما به دليل

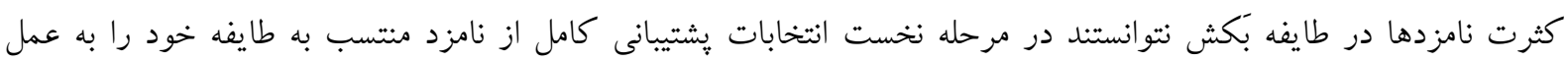

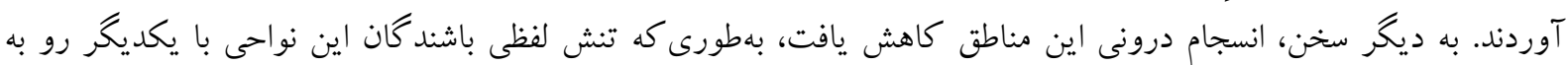

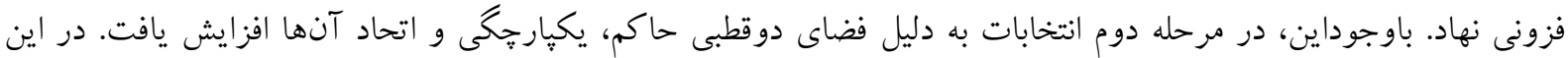

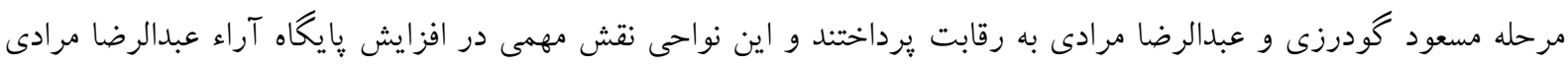

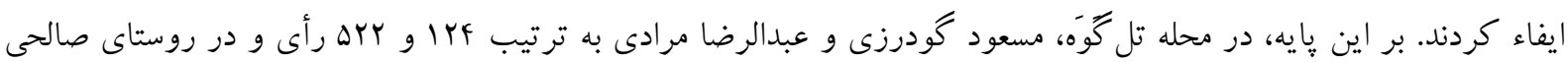

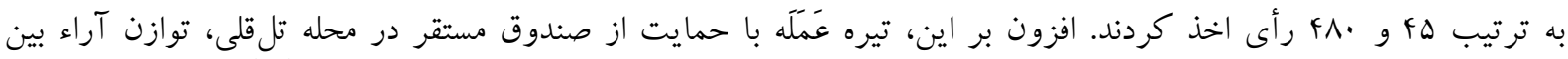

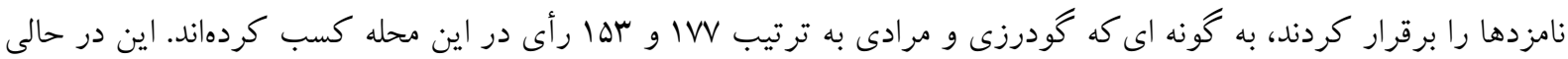

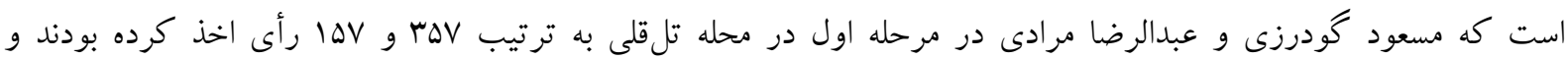

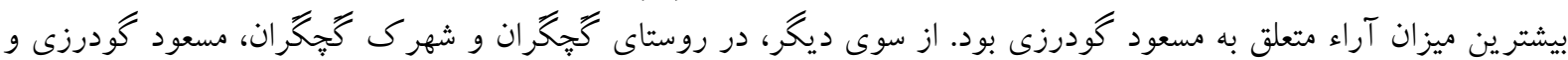
عبدالرضا مرادى به ترتيب اع| و 9 والى رأى به دست آوردند. ديخر آنكه در صندوق آبفا در مرحله اول انتخابات، مسعود

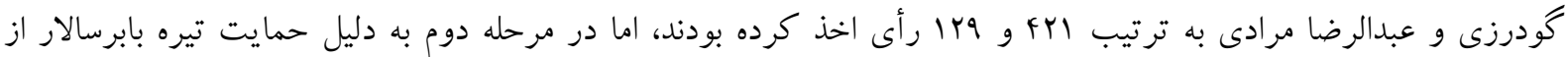

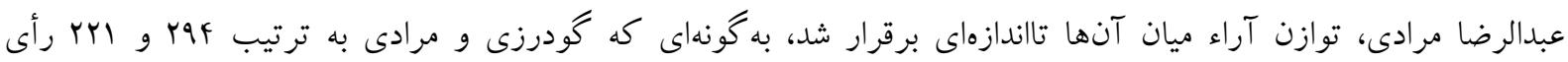

كسب كردند) (Governorate of Mamssani, 2015, 2016)

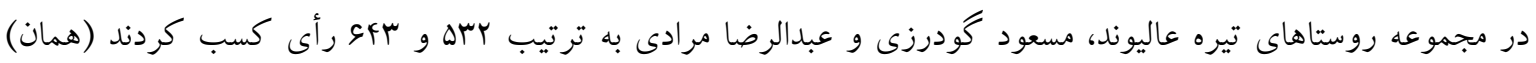

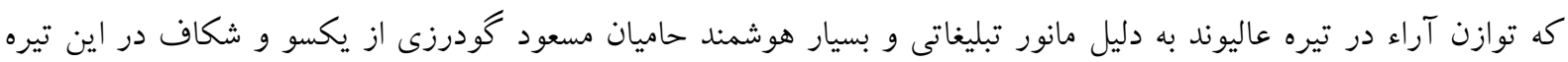

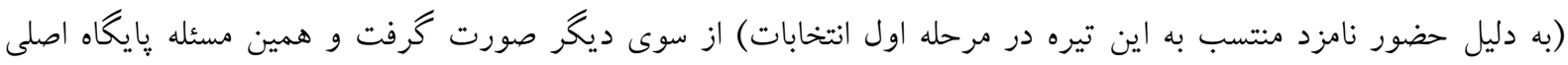
آراء عبدالرضا مرادى دريكى از مراكز بسيار مهم طايفه خود (بكش) را تضعيف كرد. اين مسئله نشان مىدهد مهد كه ساخت

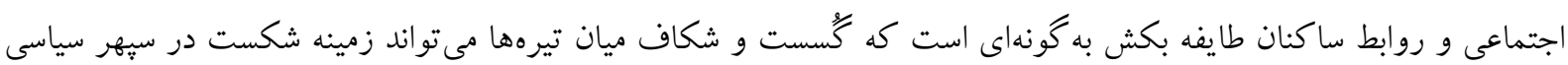

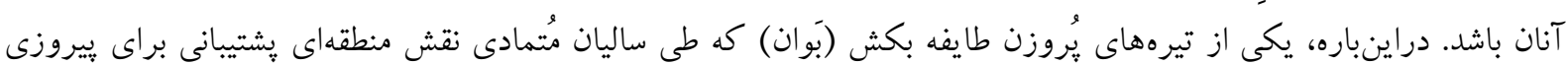

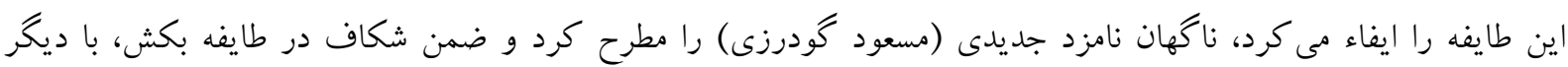

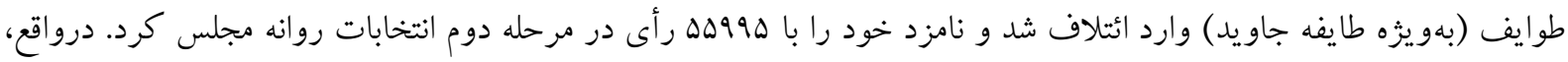




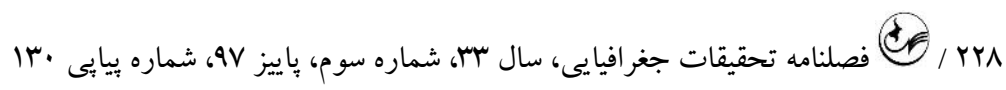
وزن زئويليتيك تيره بَوان و نيروهاى رأىدهنده برهيجان آنها در تحولات سياسى ادوار بيشين موردتوجه گروههاى ذىنفوذ

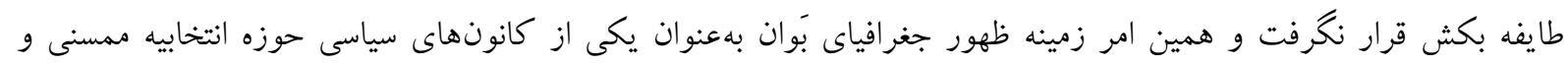
رستم شد كه هم اكنون قطب جديد در جغرافياى سياسى ممسنى به شمار مىرود. اين منطقه محلى و جغرافيايى ضمن اينكه

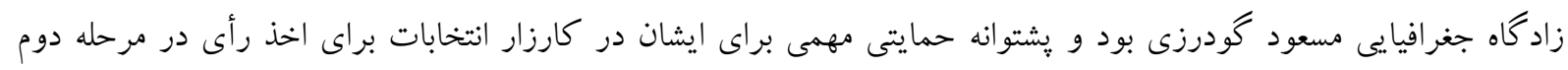

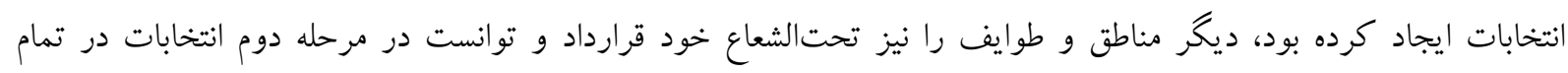

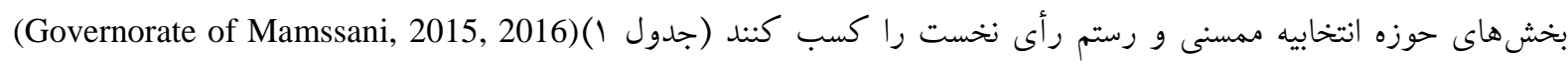

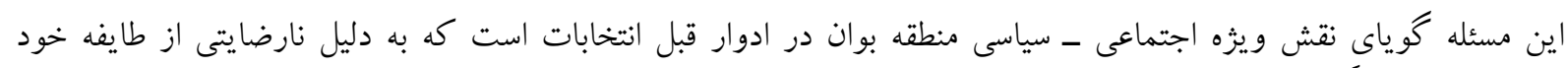

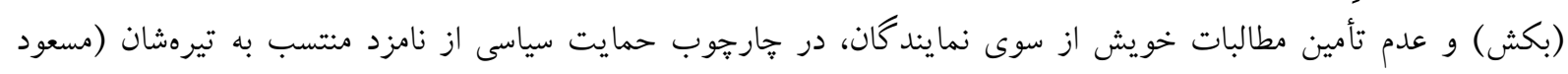

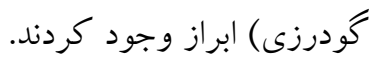

جدول ا - آراء نامزدها به تفكيك بخشها در مر حله دوم دهمين دوره انتخابات مجلس شوراى اسلامى

\begin{tabular}{|c|c|c|c|c|c|c|c|}
\hline جمع & بخش ماهورميلاتى & 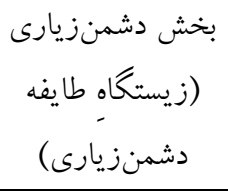 & (زيستَاه رستم طايفه & 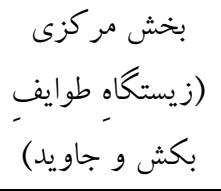 & (زيستگاه) & اسامى نامزدها & رديف \\
\hline$\triangle \Delta 99 \Delta$ & YFDF & rMAq & IVTra & אודזr & بكش & مسعود گودرزى & 1 \\
\hline$r s . r v$ & IVTs & $I V \Delta \Delta$ & 9098 & rrqo. & بكش & عبدالرضا مرادى & r \\
\hline
\end{tabular}

منبع: (Governorate of Mamssani, 2015, 2016).

شايانذكر است كه در دوره هشتم انتخابات مجلس شوراى اسلامى كه رقابت جدى ميان عبدالرضا مرادى (بكش) و على (ج) هانى

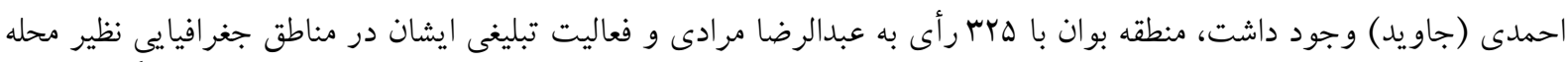

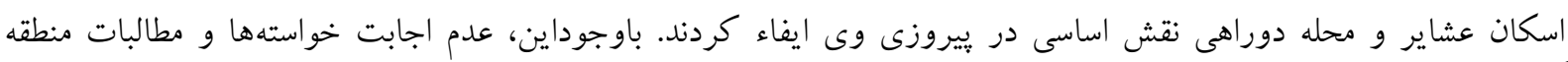

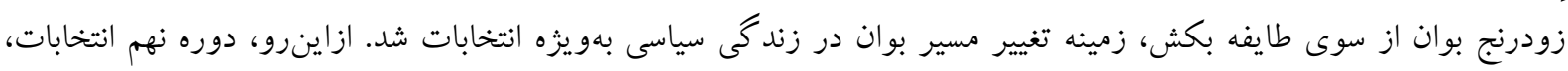

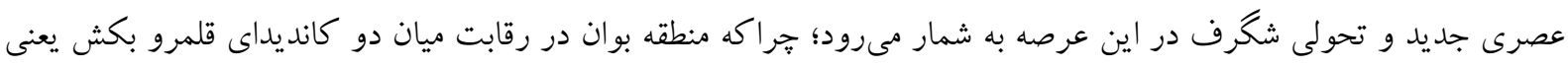

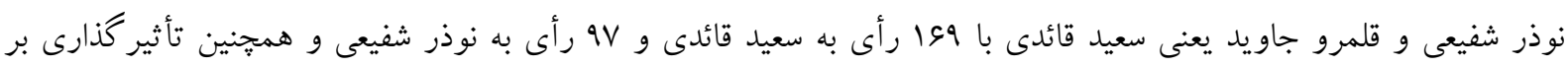

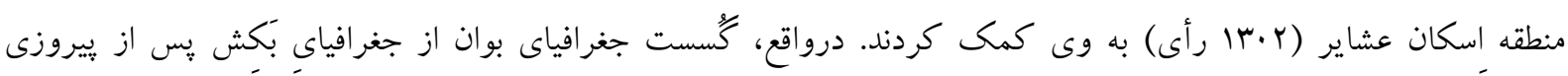

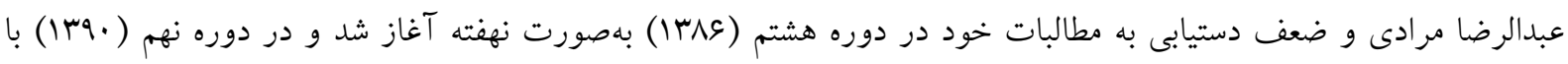

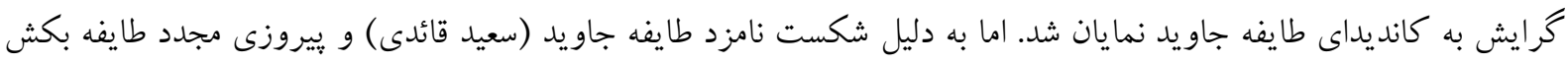

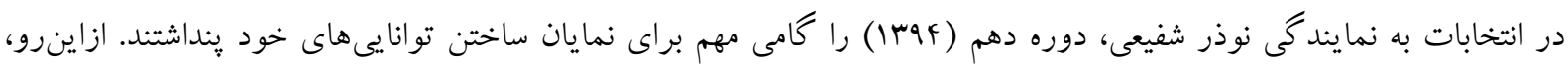

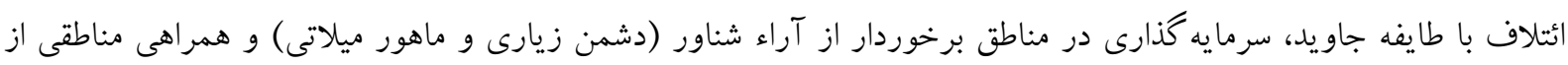

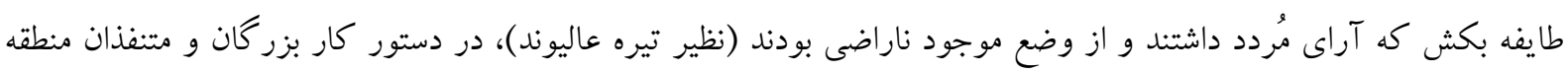
بوان قرار كرفت و همين امر زمينه ييروزى آنان شد.

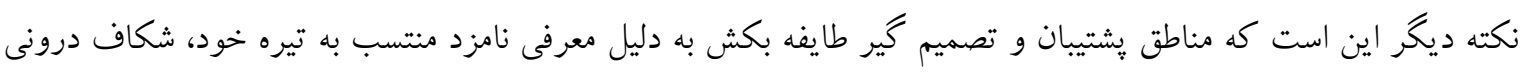

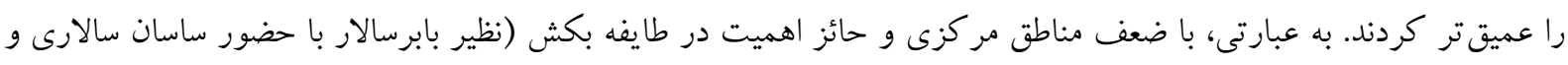

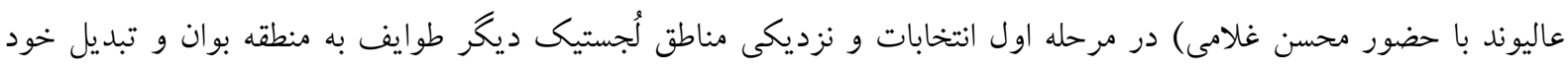

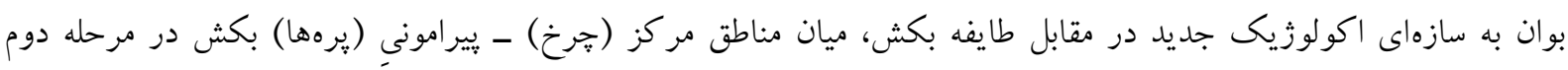

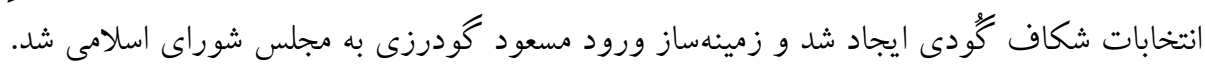


در قلمرو جغرافيايى طايفه رستم، سكونتكاههاى روستايى نظير نُو گُك و حُسين آباد تا قبل از سقوط خوانين به ترتيب

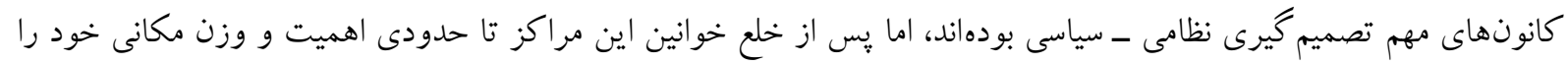

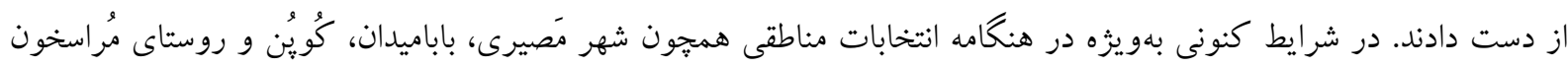

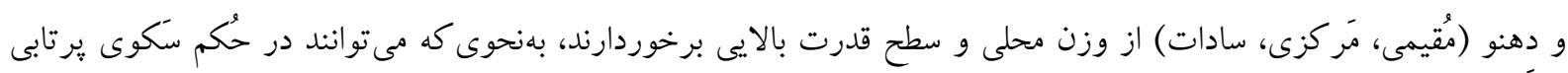

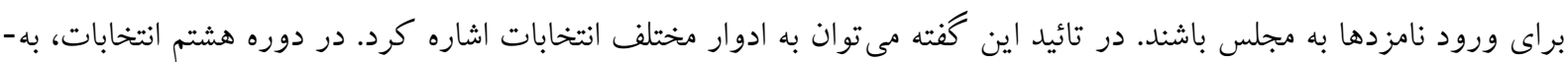

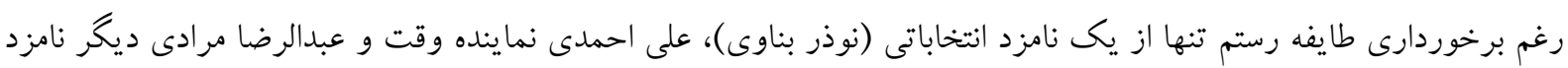

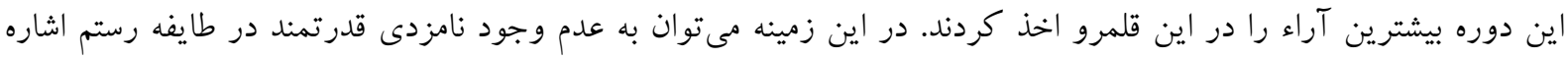

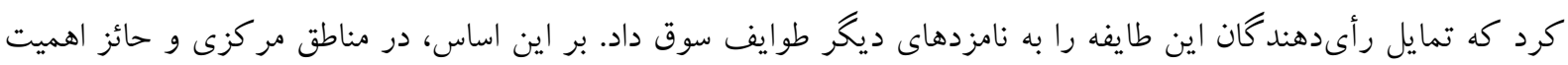

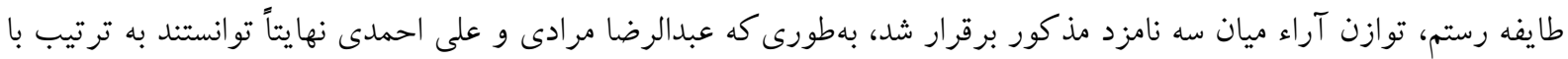

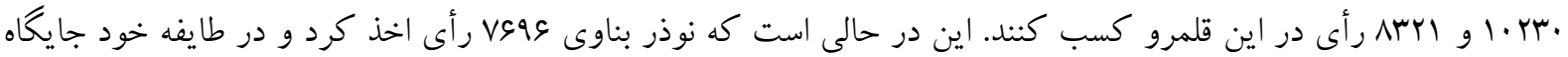

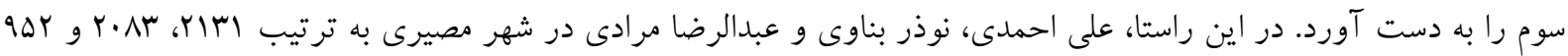

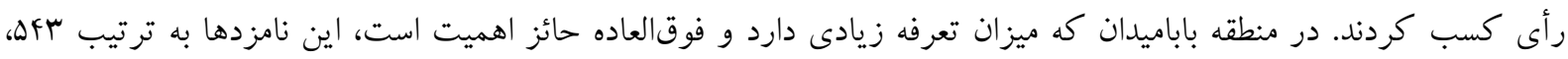

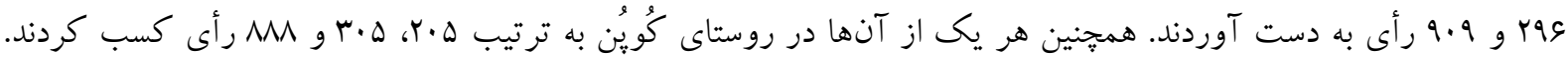

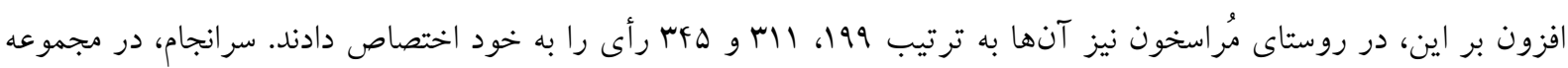

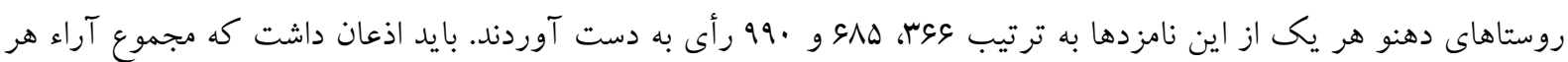

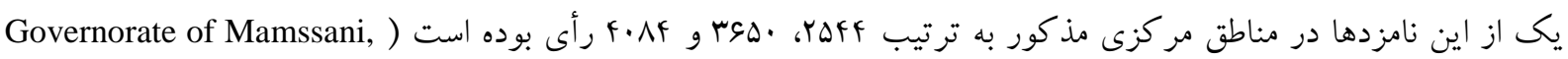

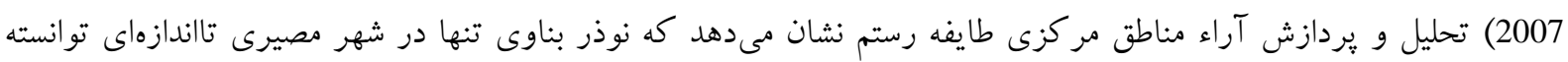

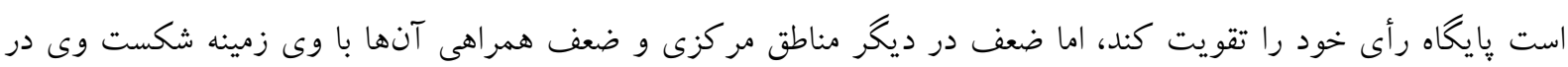

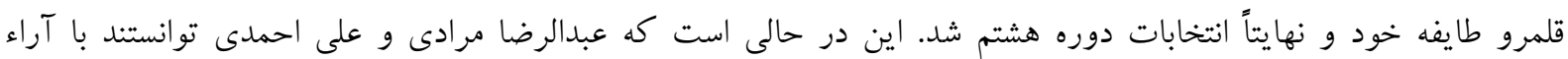

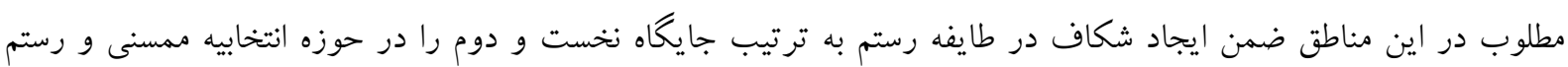

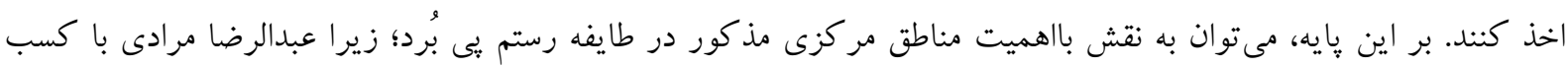

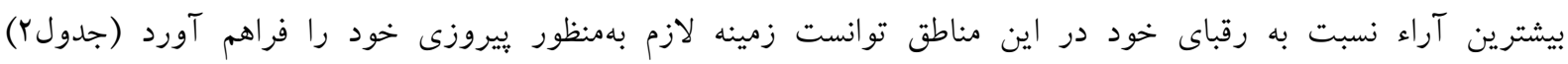

(Governorate of Mamssani, 2007)

جدول r- آراء نامزدها به تفكيك بخشها در هشتمين دوره انتخابات مجلس شوراى اسلامى

\begin{tabular}{|c|c|c|c|c|c|c|c|}
\hline جمع آراء & بخش ماهورميلاتى & بخش دشمنزيارى & بخشر (زيستماه & 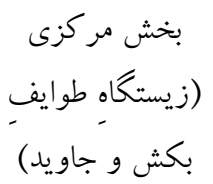 & (زيستهاه) & اسامى نامزدها & رديف \\
\hline DIDST & $r \cdot r q$ & maqs & 1. & MFYMA & بكش & عبدالرضا مرادى & 1 \\
\hline rVrql & Y^৭V & MIST & NMrl & rrql. & جاويد & على احمدى & r \\
\hline$\Lambda \Delta V F$ & $r V r$ & 1.9 & Vदqs & 499 & رستم & نوذر بناوى & r \\
\hline
\end{tabular}

(Governorate of Mamssani, 2007)

در رابطه باهميت اين مناطق در دوره دهم انتخابات نيز بايد اشاره داشت كه آمار مرحله نخست و دوم نشان مىدهد كه در مرحله اول انتخابات، مجيد انصارى، سيد يداله حسينى و سيد جعفر هاشمى (نامزدهاى طايفه رستم) در ״ينج منطقه يادشده بيشترين آراء را به دست آورند، اما نامزدهاى ديخر طوايف، آراء بسيار ناجيزى (حتى صفر) در اين مناطق اخذ كردهاند. سه 


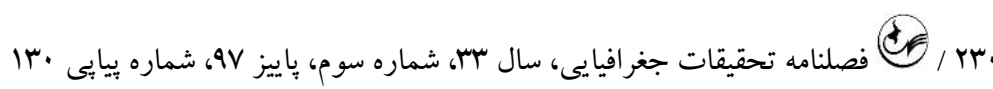

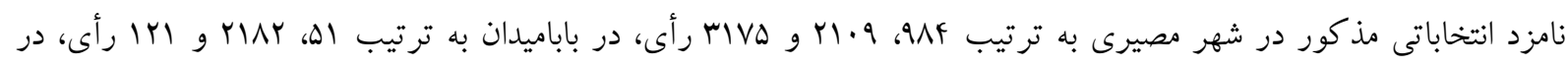

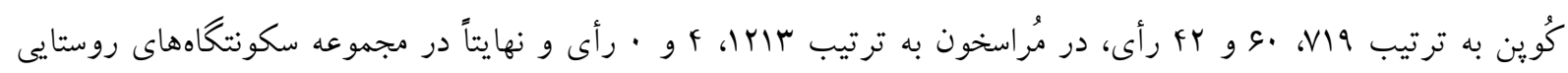

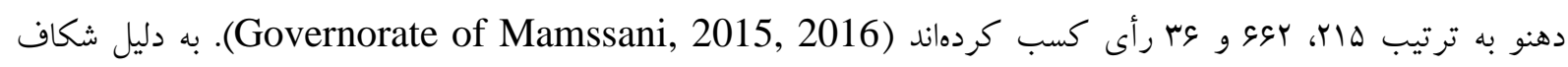
فرهنكى ـ اجتماعى ميان مناطق مذكور و حضور سه نامزد از طايفه رستم در مرحله اول انتخابات به شكنندگى مجموع آراء

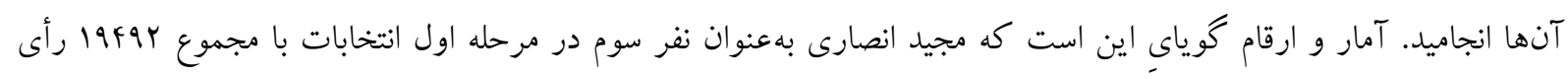
(بعد از مسعود گودرزى و عبدالرضا مرادى) علىرغم كسب آراء بسيار بالا در بخش سُورناى رستم (ازجمله مناطق مهمى نظير كُوِين و مُراسخون) نتوانست در بخش مر كزى رستم (كه شامل سه منطقه مهم يعنى مصيرى، باباميدان و دهنو است) آراء قابل توجهى اخذ كند و همين مسئله درراه نيافتن وى به مرحله دوم انتخابات نقش قابل توجهى داشته است. از سوى ديخر، سيد يدالله

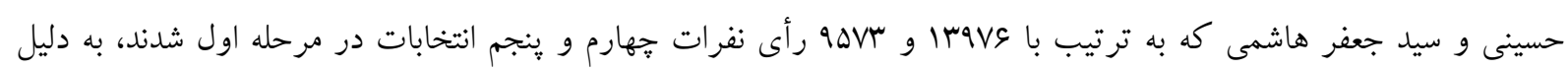

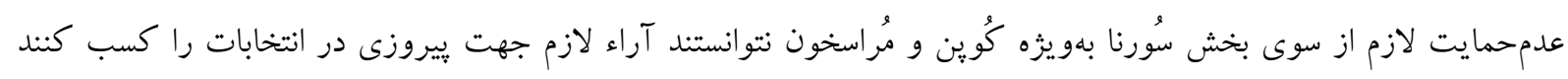
(جدول r) (Governorate of Mamssani, 2015, 2016). ازاينرو، مىتوان به تضاد و تعارض ميان مناطق حساس و و

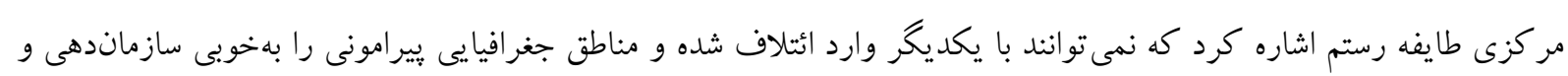
بسيج كنند.

جدول r - آراء نامزدها به تفكيك بخشها در مرحله اول در دهمين دوره انتخابات مجلس شوراى اسلامى

\begin{tabular}{|c|c|c|c|c|c|c|c|}
\hline جمع & 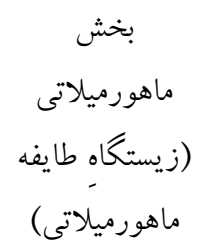 & 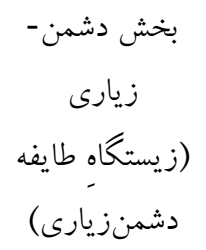 & طايفه رستم) & 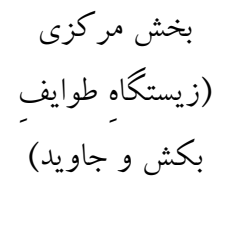 & (زيستگاه) & اسامى نامزدها & رديف \\
\hline | & IfV. & $r \cdot \Delta f$ & IVAD & $r \cdots \wedge r$ & بكش & مسعود گودرزى & 1 \\
\hline rrmag & 1894 & $|V|$. & TAFD & ISFFV & بكش & عبدالرضا مرادى & r \\
\hline lafar & $|\wedge|$ & $4 \cdot 9$ & IrMAr & 0.19 & رستم & مجيد انصارى & $r$ \\
\hline Irqve & TrV & f.r & $1 . \mathrm{FFV}$ & rvqq & رستم & سيد يدالله حسينى & f \\
\hline $9 \Delta V$ & $r \cdot V$ & Va & STYV & $r \cdot s q$ & 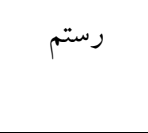 & سيد جعفر & $\Delta$ \\
\hline
\end{tabular}

(Governorate of Mamssani, 2015, 2016)

در مرحله دوم انتخابات در شهر مَصيرى و محله هاى مختلف آن، مسعود كودرزى و عبدالرضا مرادى نامزدهاى راهيافته به

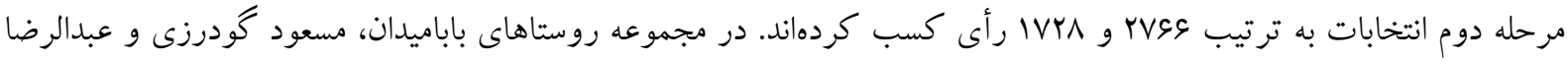

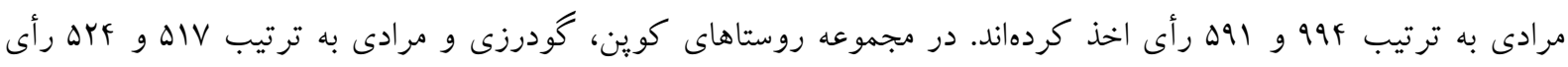

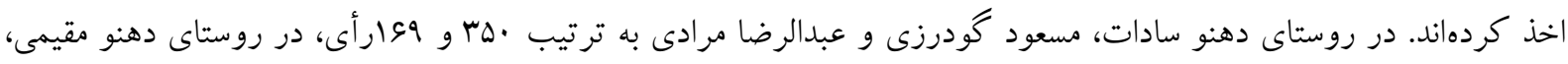

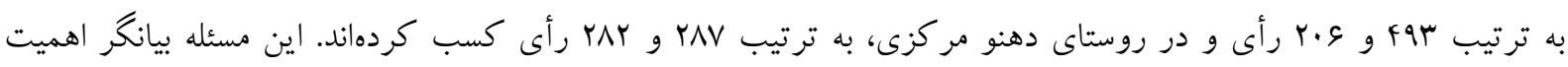

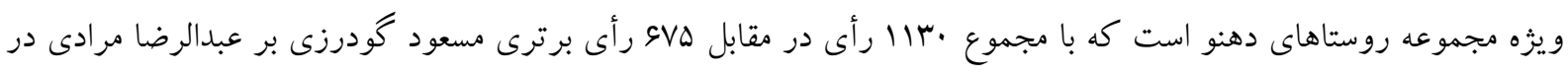

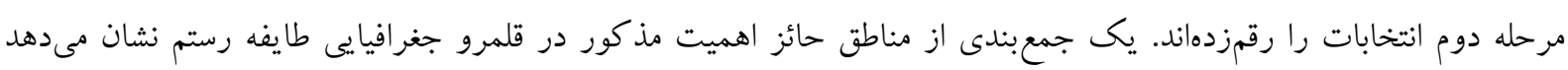




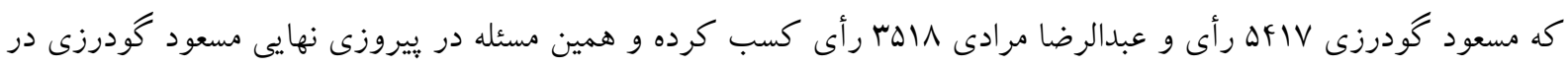

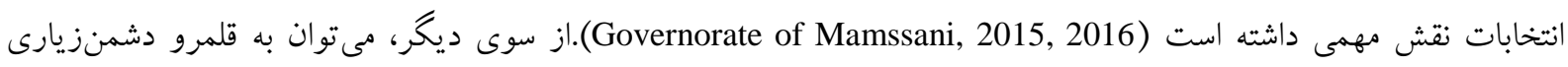

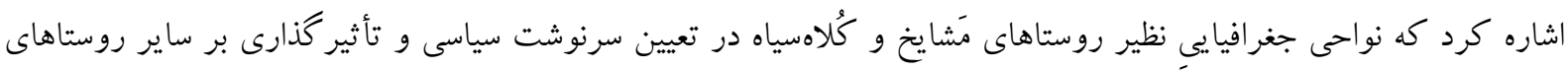

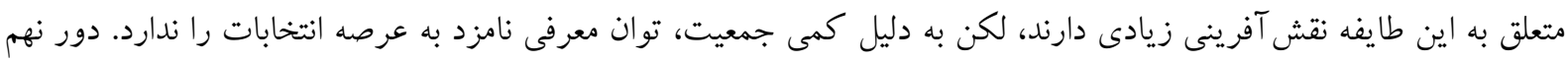

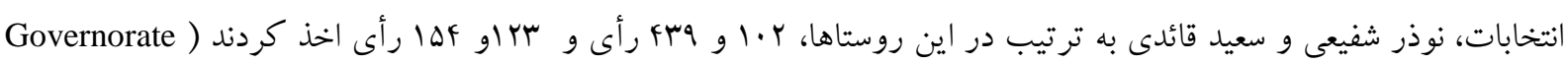

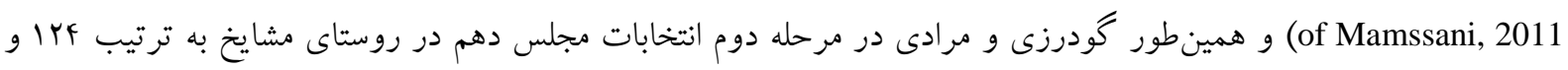
99 رأى، در كُلاه سياه به ترتيب ه.r و و عاس رأى كسب كردند (Governorate of Mamssani, 2015, 2016).

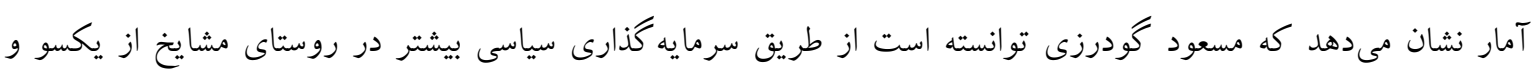

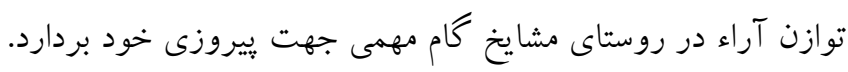

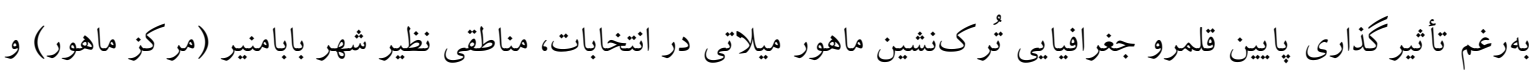

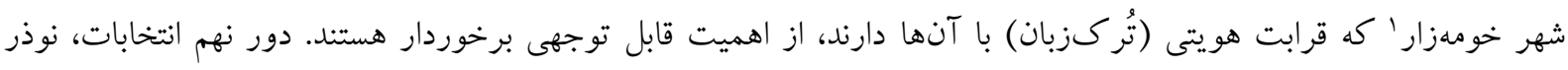

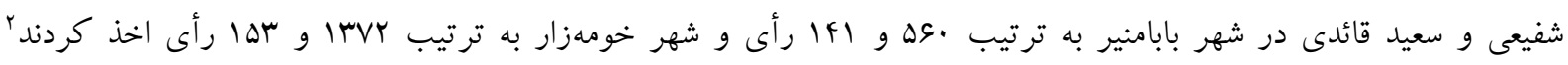

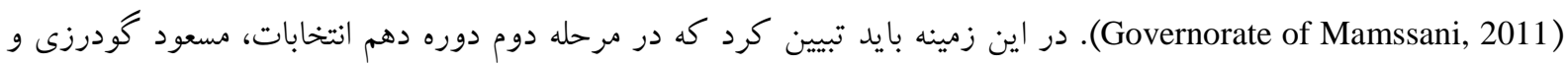

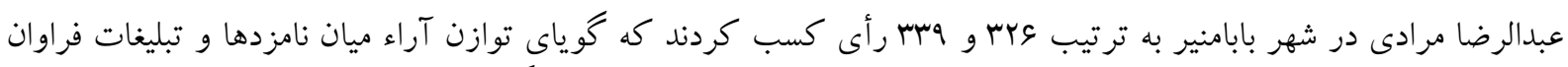

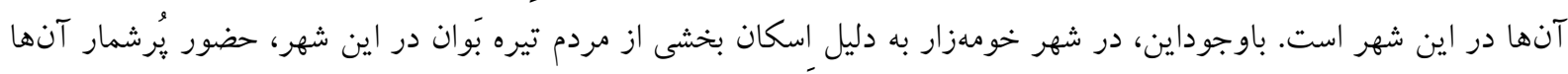

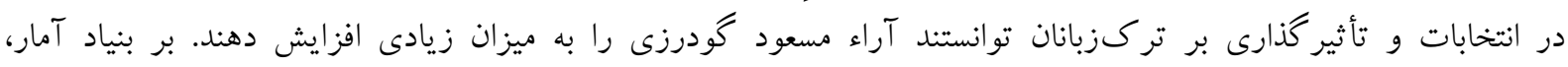

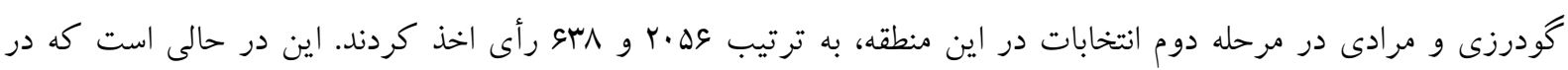

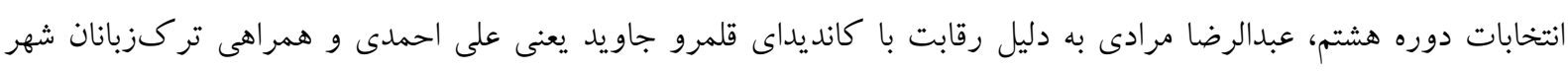

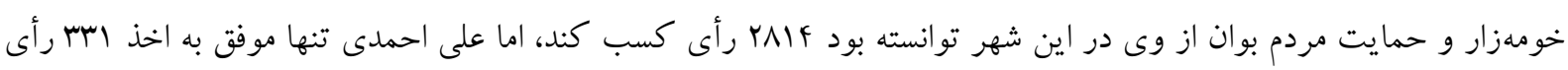

در اين شهر مهم شد (Governorate of Mamssani, 2007, 2015, 2016).

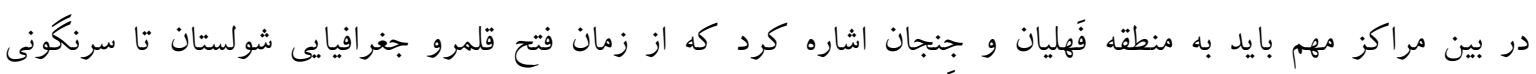

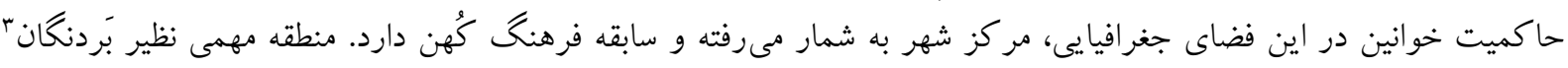

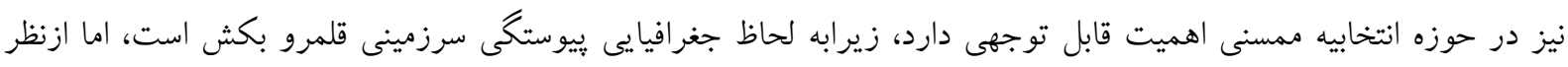

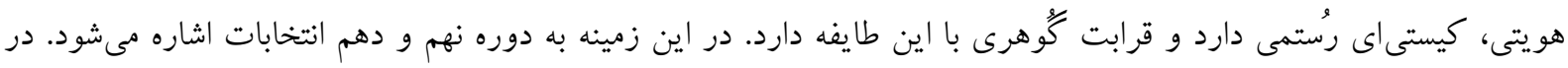

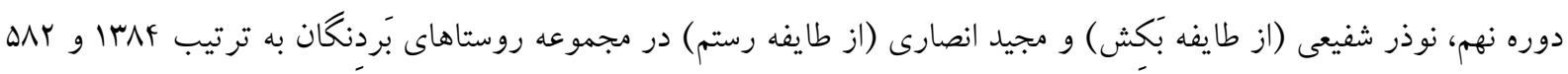

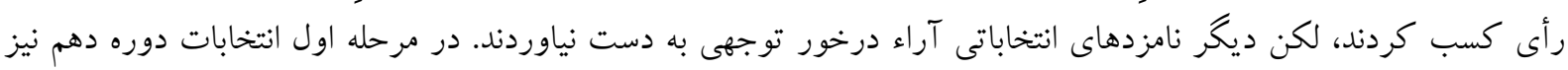

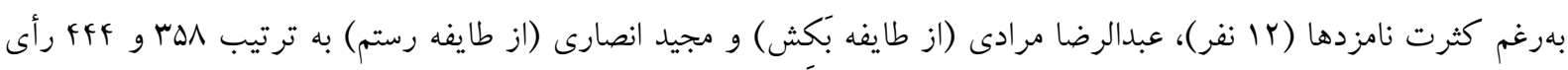

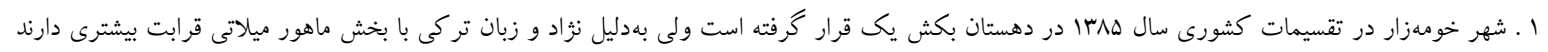

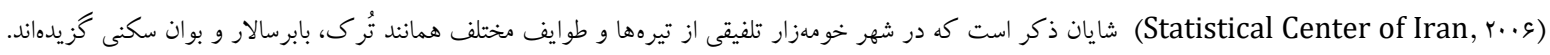

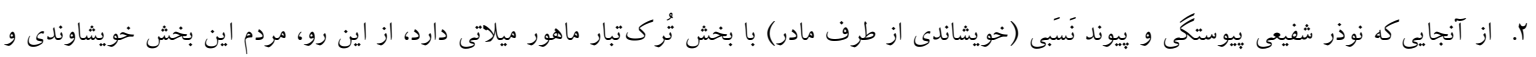

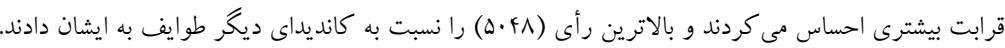

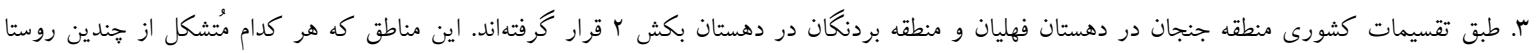

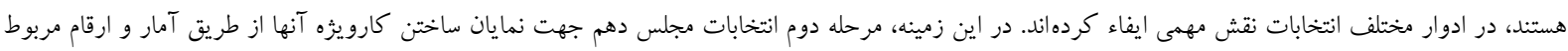
به آراء نامزدهاى انتخاباتى مورد تجزيه و تحليل قرار كرفته است.
} 


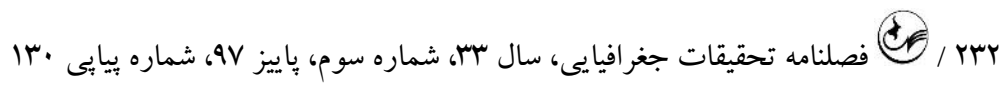

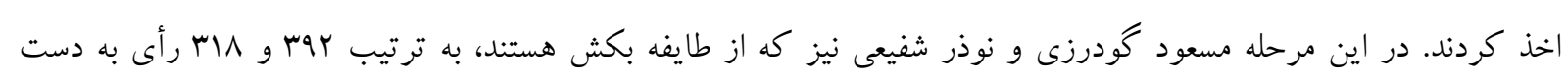

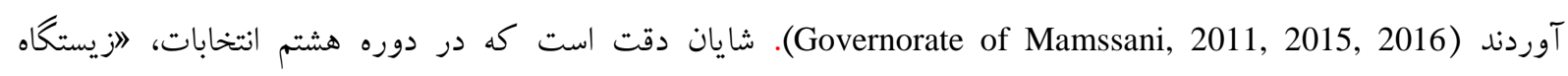

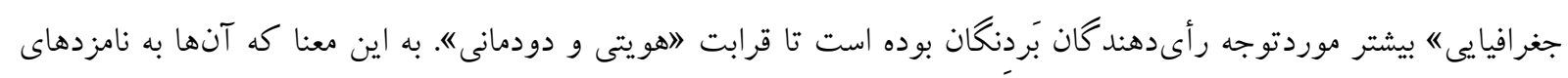

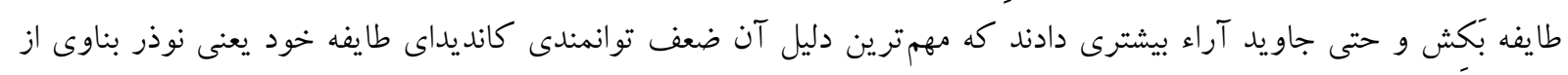

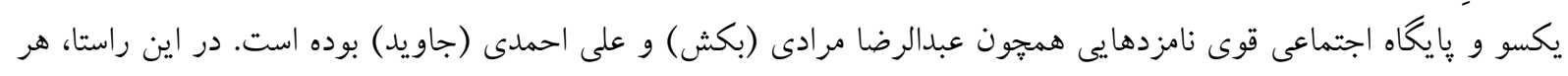

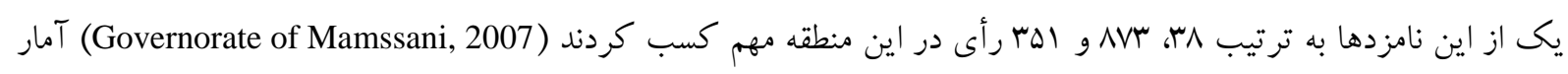

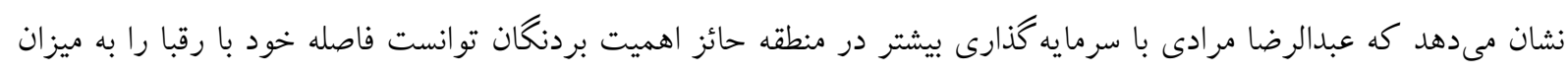
زيادى افزايش دهد.

درباره اهميت و نقش مناطق فَهليان و جِنجان بايستى اشاره داشت كه در دوره هشتم انتخابات مجلس و در رقابت دريت بين

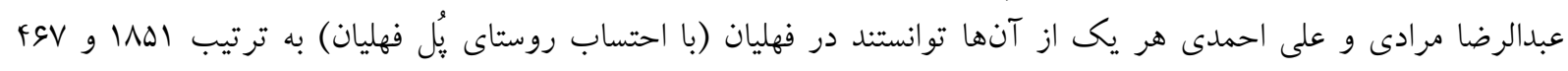

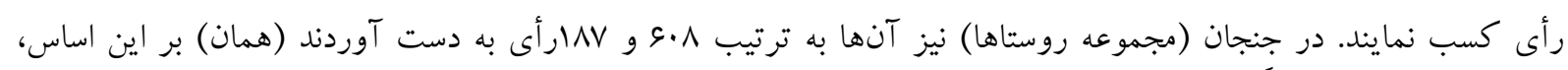

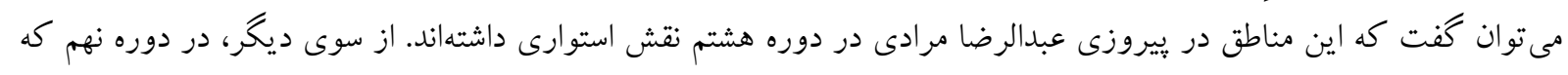

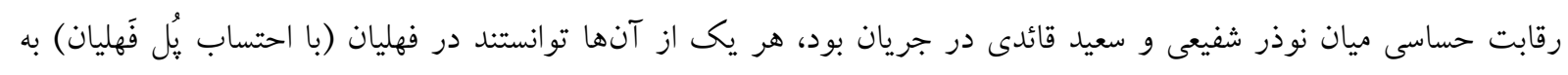

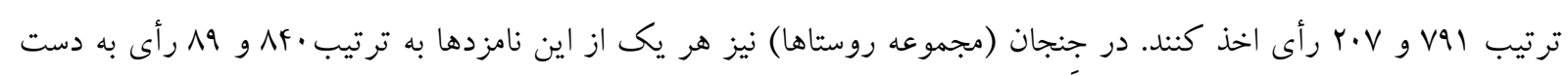

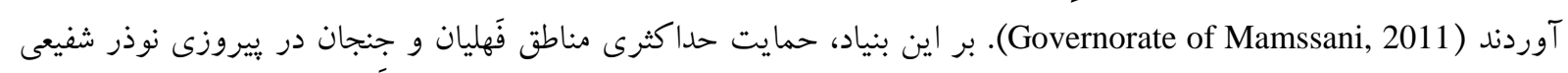

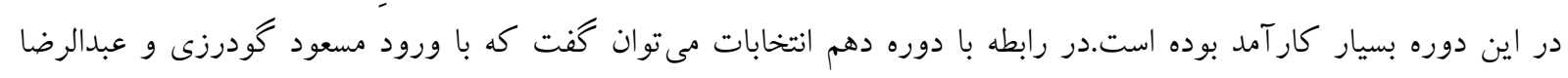

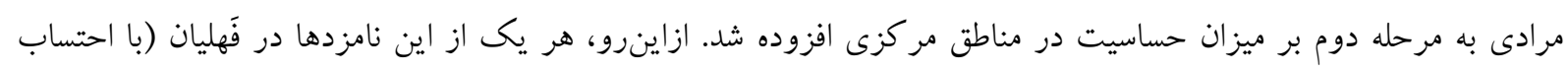

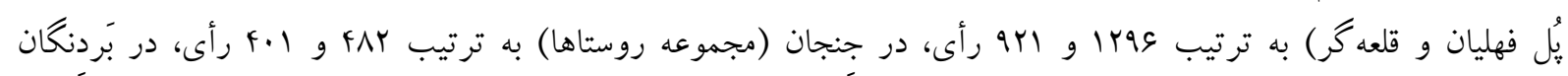

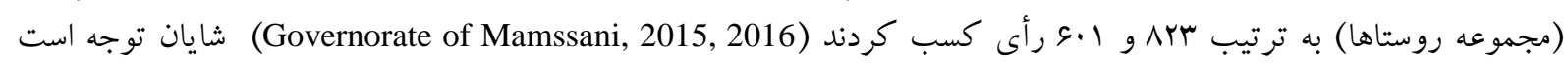

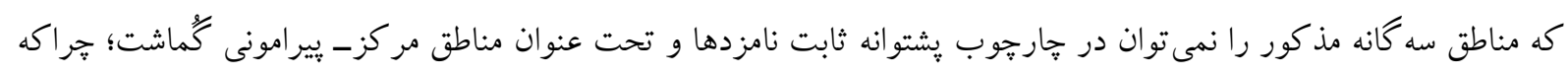

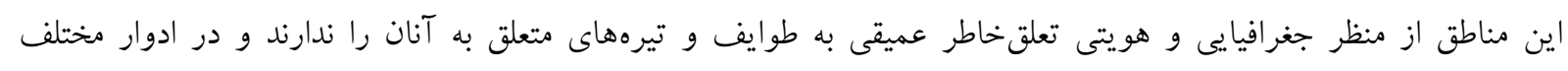

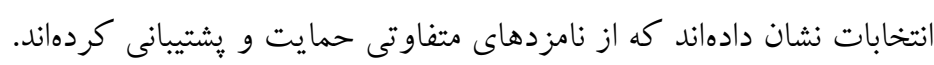

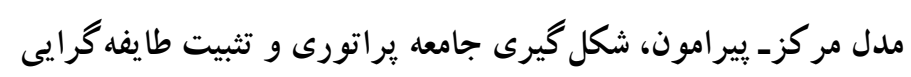

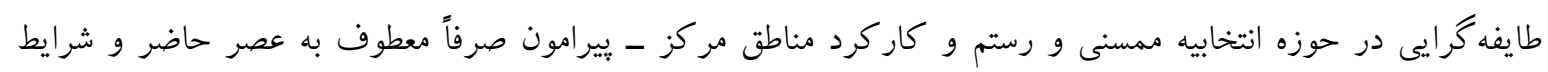

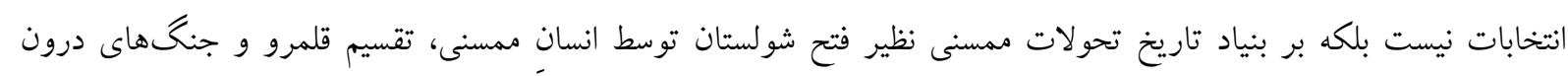

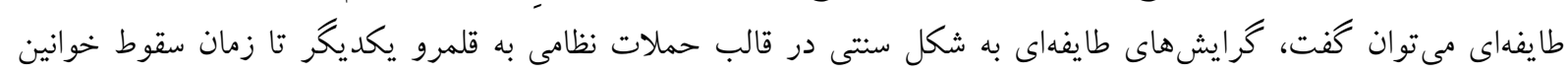

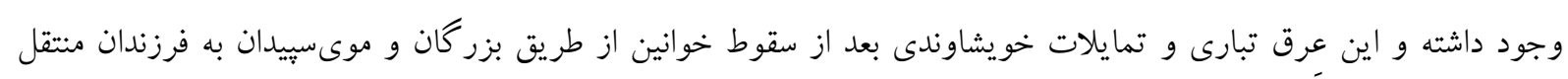

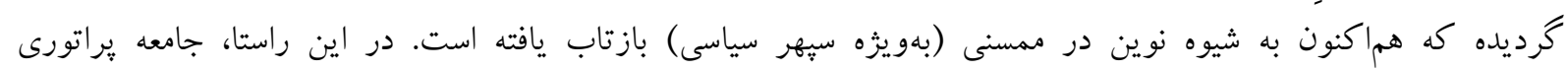

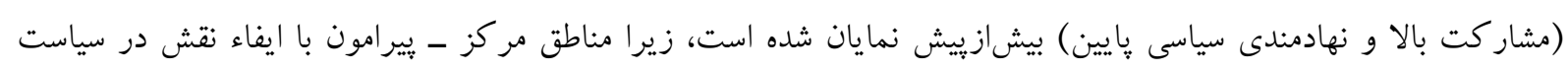

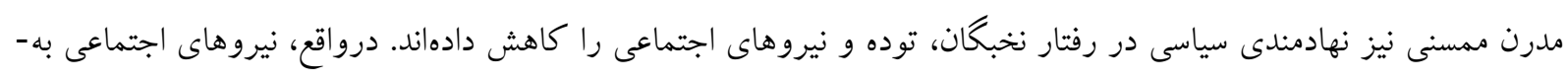

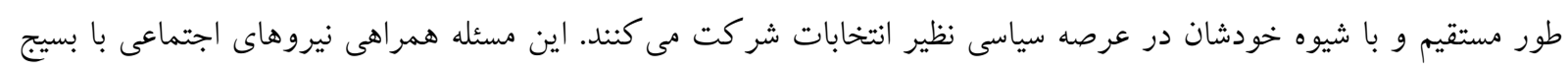

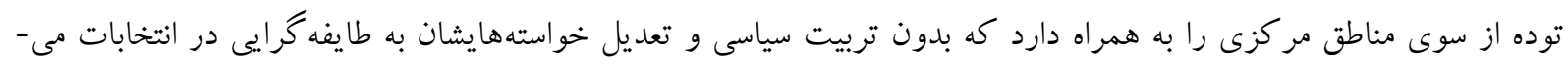


يردازند. بنابراين، روشهاى مشروع و معتبر موردنظر شركت كنند كان در انتخابات وجود ندارد بلكه اطاعت فرامين و اجابت

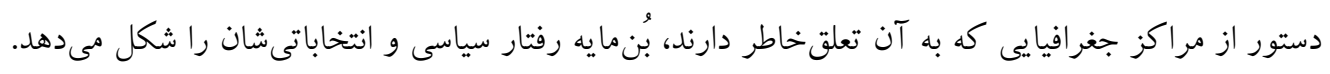

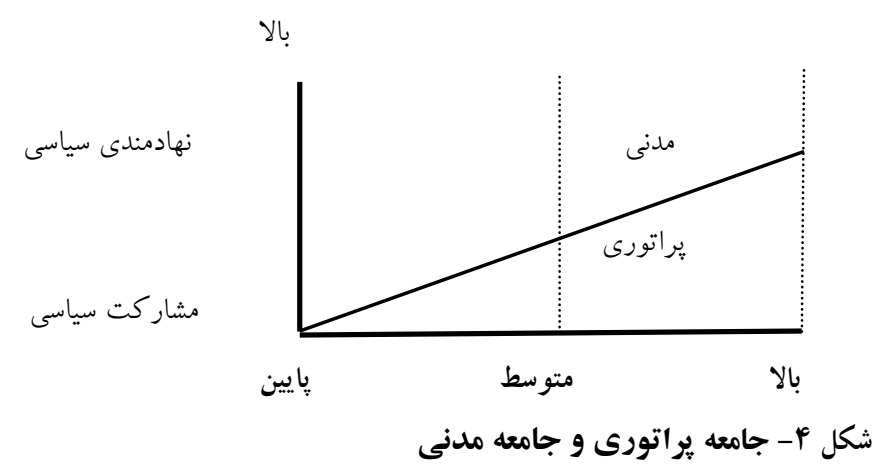

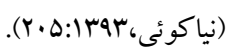

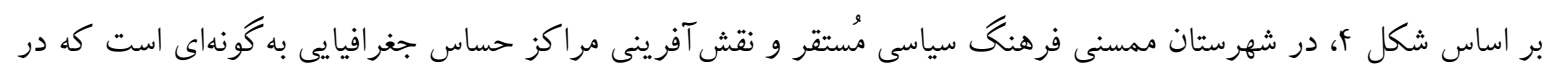

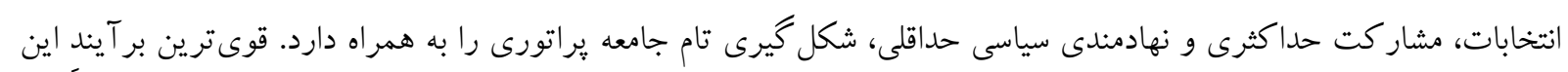

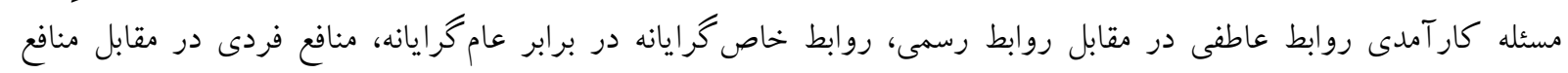

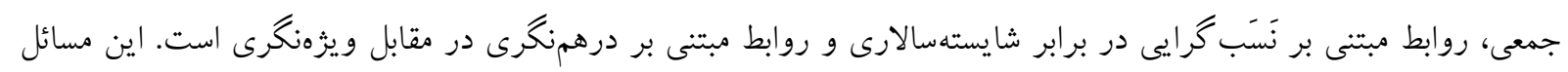

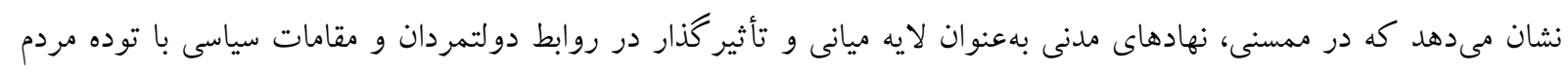

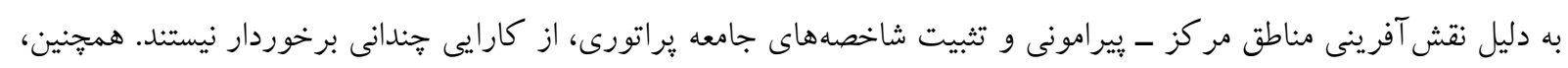

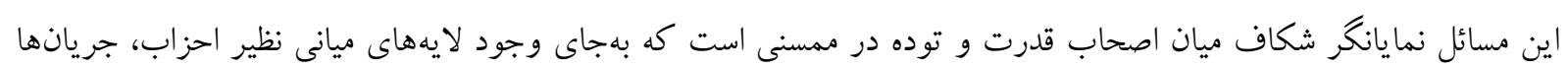

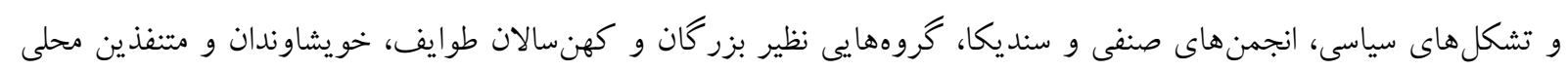

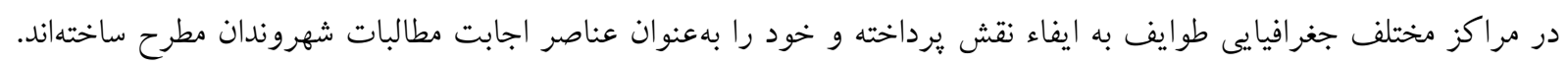

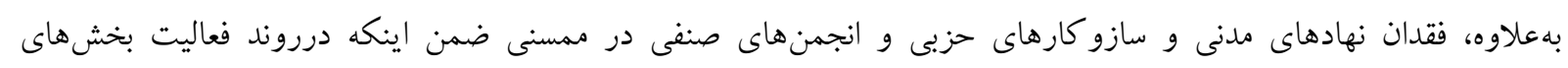

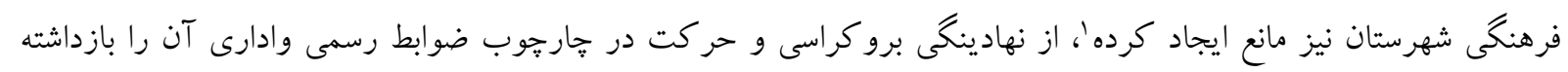

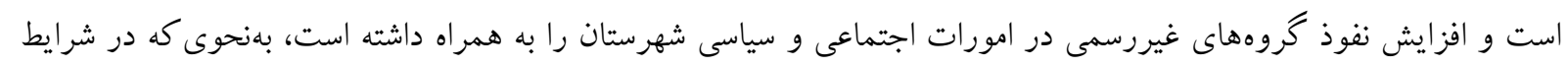

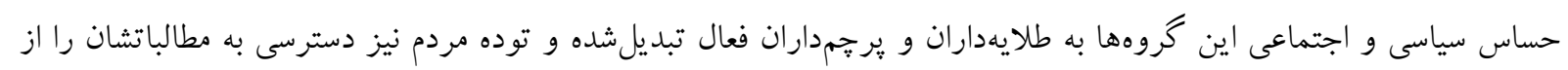

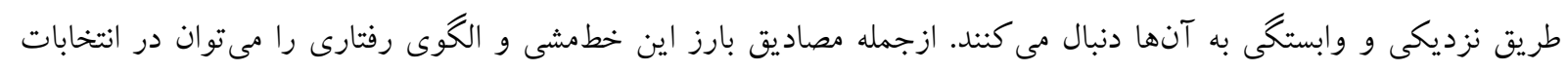

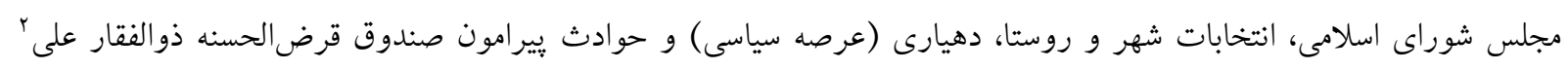

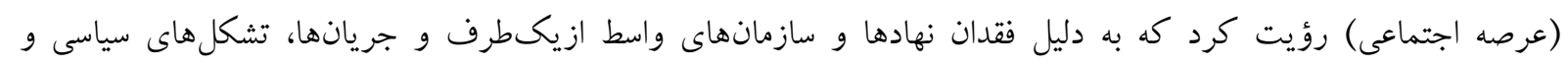

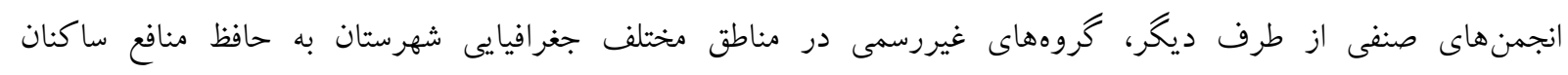

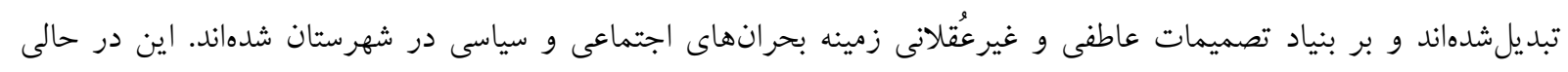

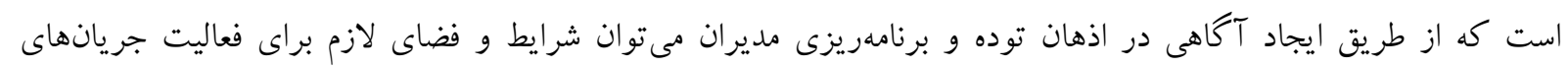

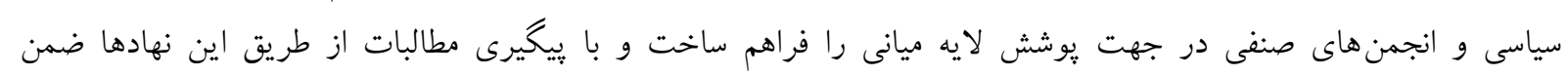

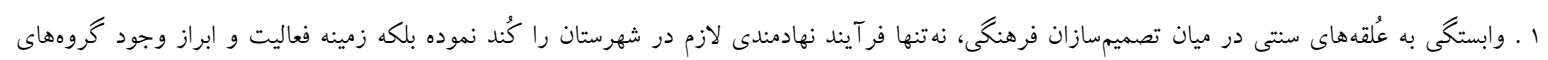

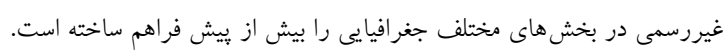

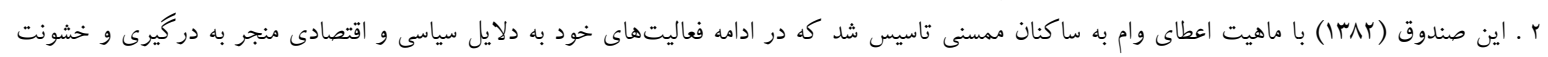

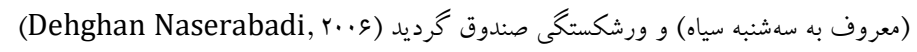




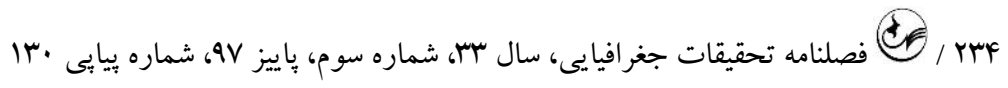
جلو كيرى از وقوع جالشهاى عملياتى'، كام مهمى بهسوى توسعه شهرستان برداشت. در مدل شماره ا مى توان سه لايه را در

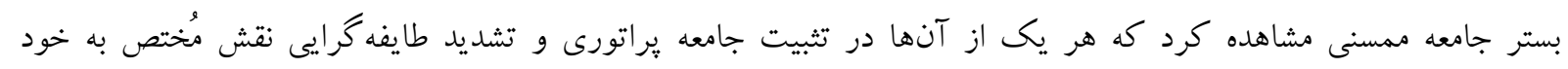

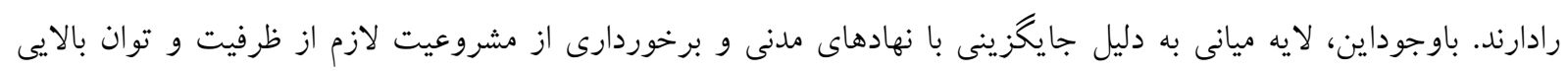

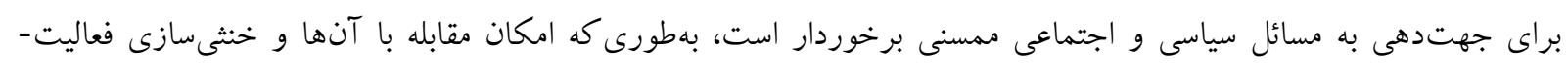

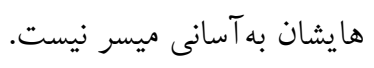

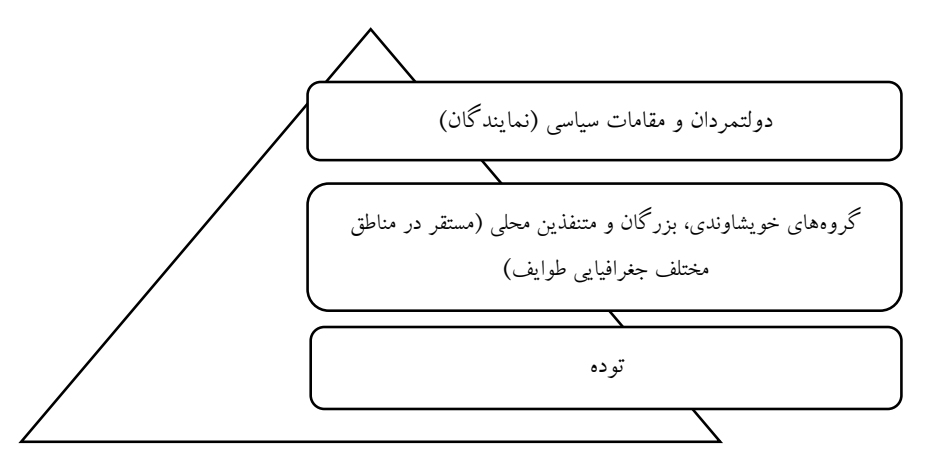

شكله - لايههاى سياسى و اجتماعى در حوزه انتخابيه ممسنى و رستم

\section{نتيجه گيرى}

يافته هاى بثزوهش نشان داد كه وابستكى و تعلق خاطر باشند گانِ ممسنى به زادكاه و زيستگاه جغرافياى خود سابقهاى ديرينه

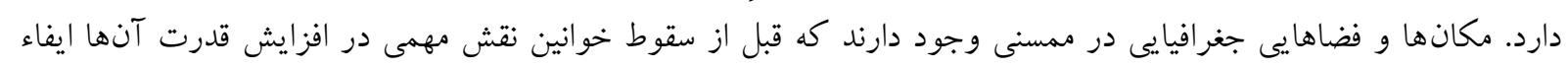

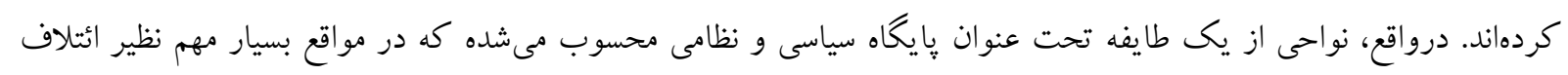

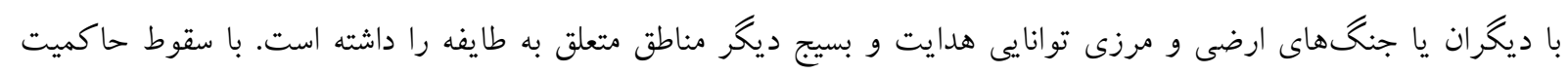

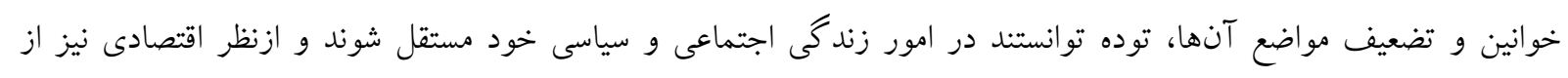

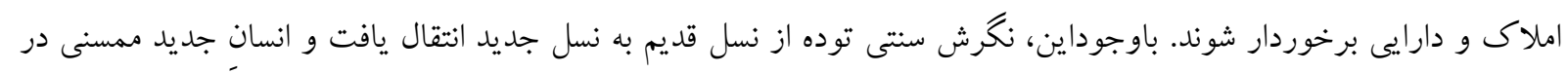

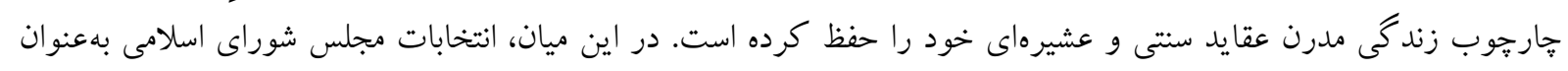

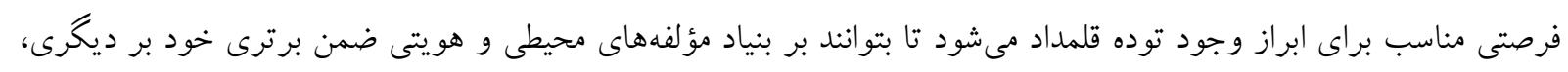

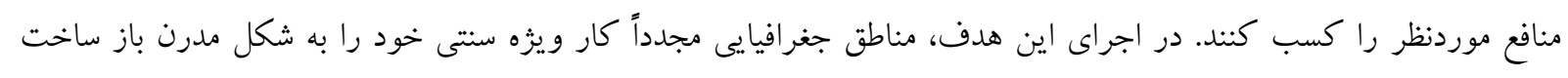

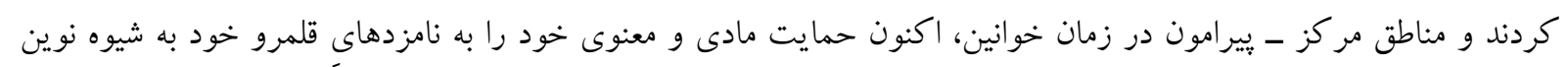

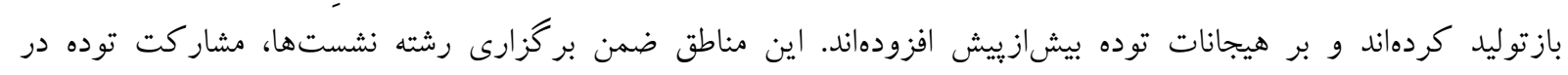

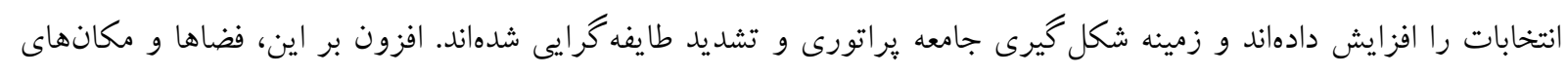

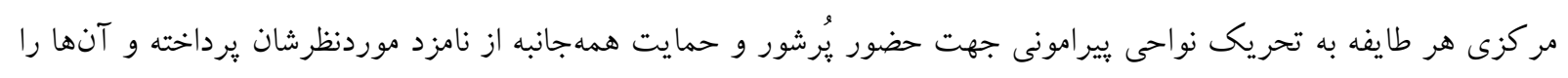

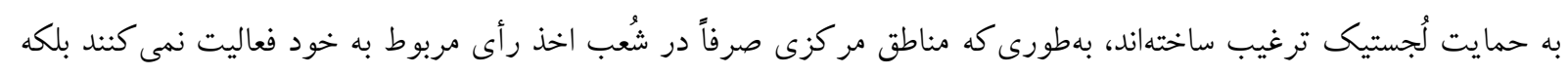

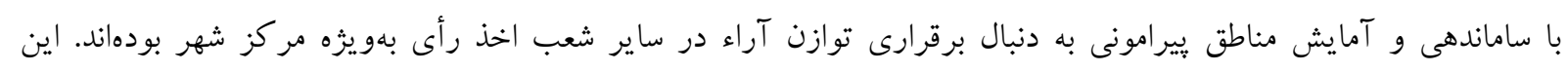

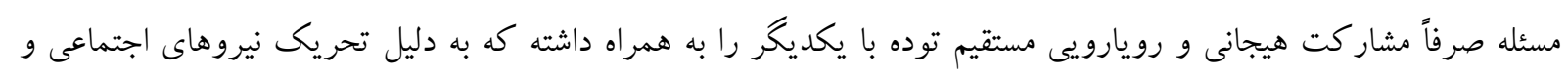

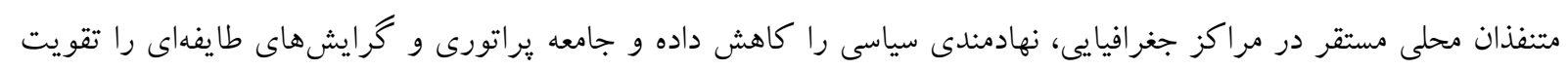

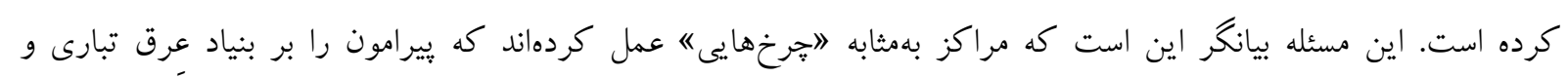


زاد كاهى مانند "پيرههايىى" ساماندهى و بسيج كردهاند. همجنين بايد كفت كه نقش آفرينى مناطق مركزى صرفاً محدود به دوره-

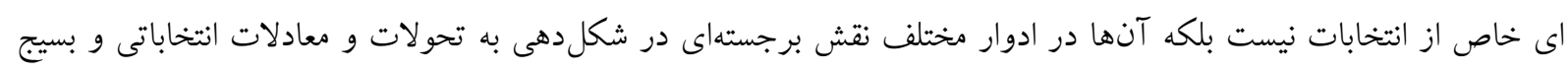

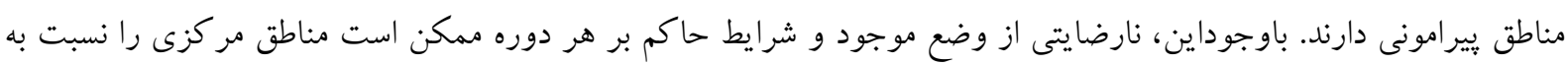

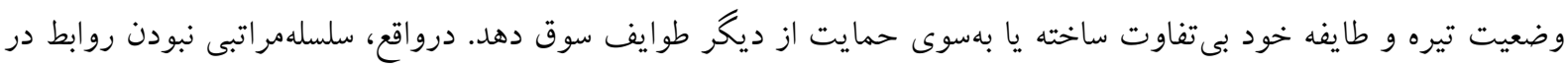

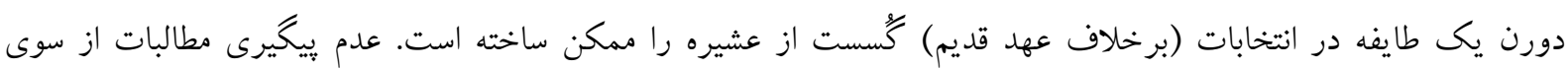

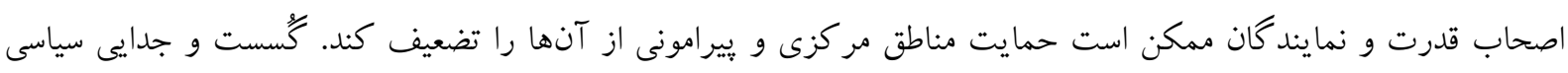

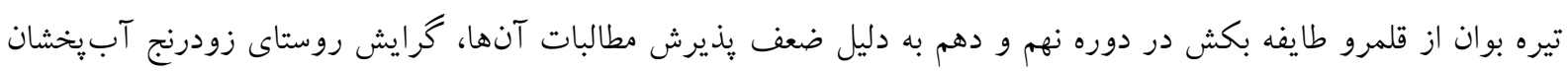

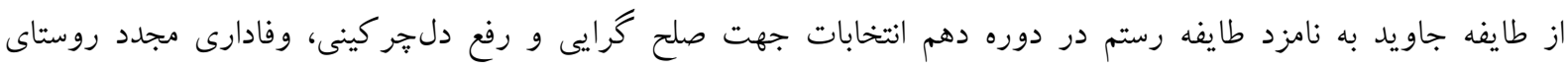

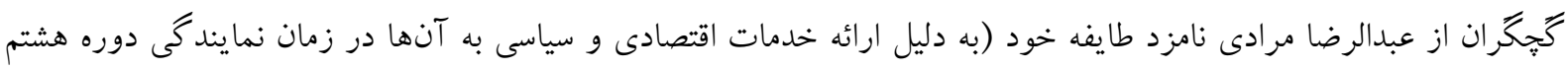

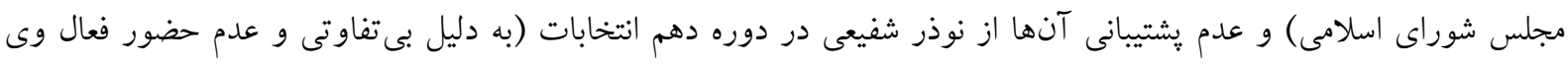

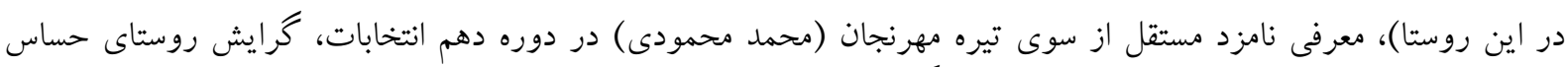

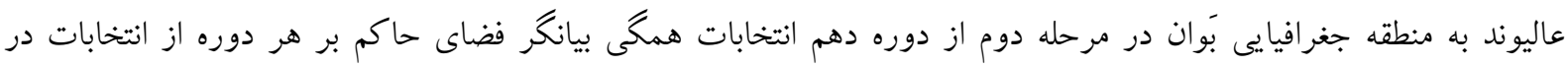

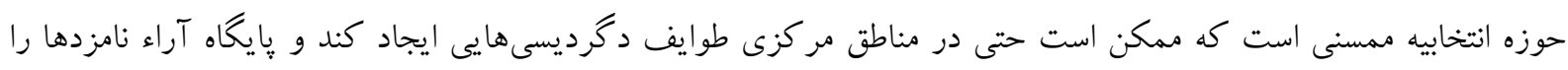

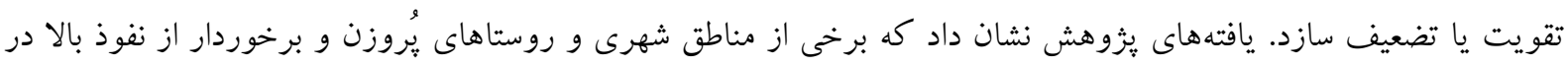

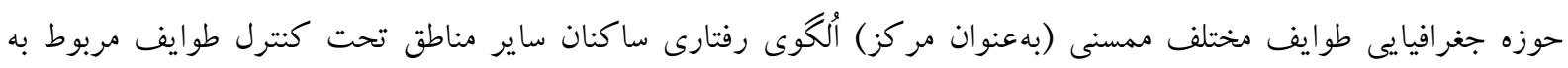

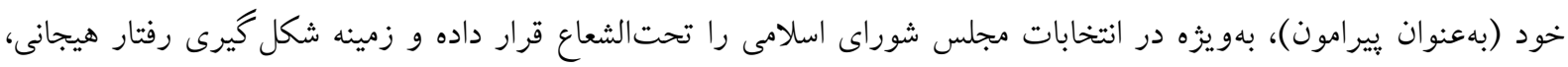

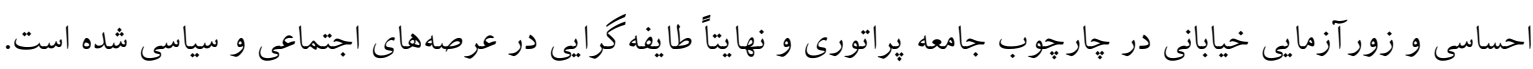

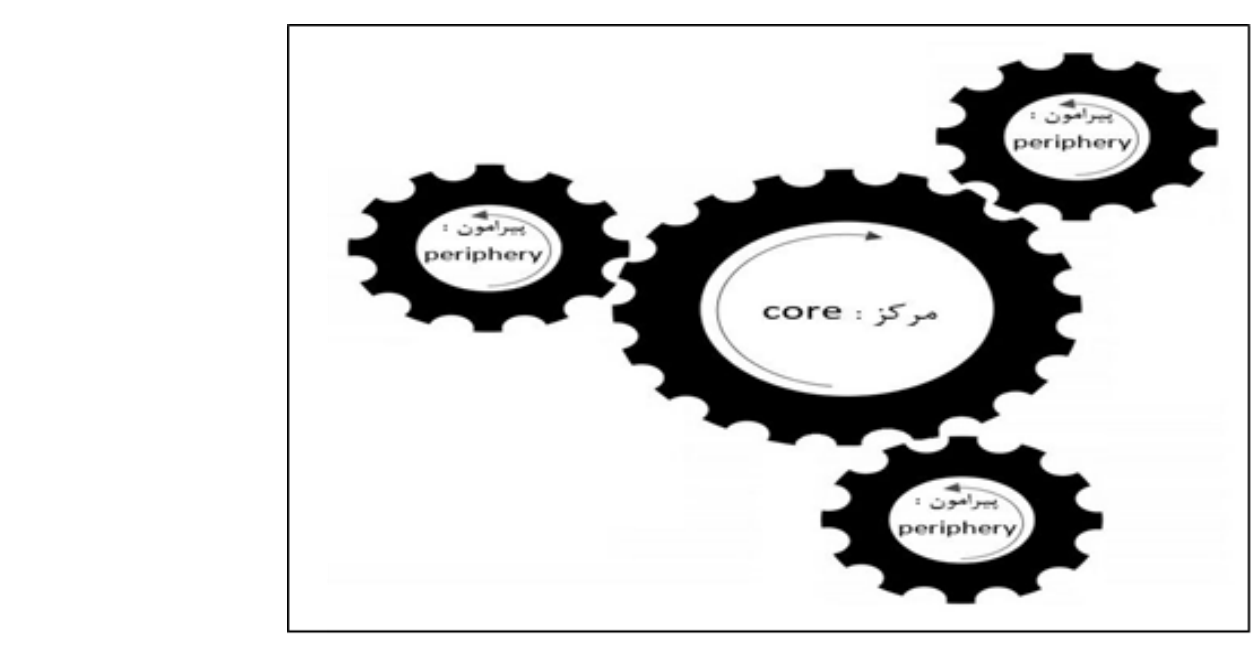

شكل 4 - مركز ( جرخ) و بيرامون (يره)

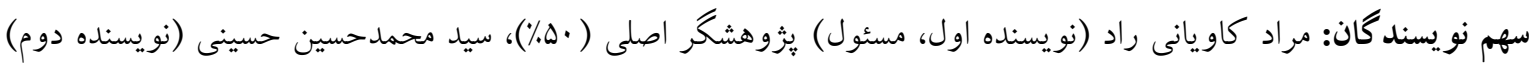

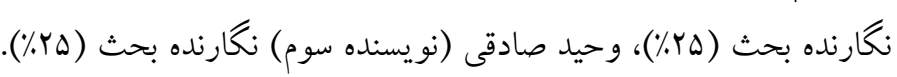

Ahmadipour, Z., \& Karimi, M. (2013). Patholigy of election in Iran, case study: Islamic consulative assembly election. Paper presented at the National Conference Geography of Election, Tehran. (Persian)

Bashirie, H. (2001). Democracy lessons for everyone. Tehran: Negahe Moaser. (Persian)

Bashirie, H. (2011). The history of Marxist ideas, . Tehran: Ney. (Persian) 


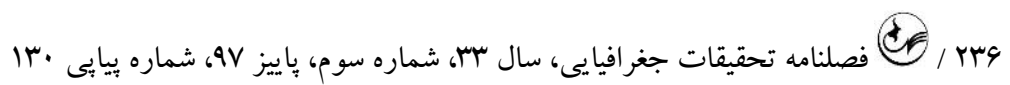

Dadashpour, H., Alizadeh, B., \& Madani, B. (2011). Review and analysis of development trends and spatial disparities in the West Azerbaijan province. Social Sciences Quarterly, 18(53), 173-208. [DOI:10.22054/QJSS.2011.6830]. (Persian)

Dehghan Naserabadi, E. (2006). The story and secrets of the Sandogh Zoalfaghar. Shiraz: Kooshamehr.

Delavari, A. (2008). The study of the roots of violence and political instability in Iran. (PhD Thesis), University of Tehran. (Persian)

Deputy of Planning and Employment of Fars Province. (2014). Statistical Yearbook of Mamassani County 20112012, . Office of Statistics and Information, 21, 1-63. (Persian)

Eghtedari, A. (1996). Khouzestan and Kohgiloie and Mamassani. Tehran: Ayat Cultural Inistitution Publication. (Persian)

Estes, T. (2006). Where the votes are: The electoral geography of the coming democratic majority. The Forum, 3(4), 1-39. [DOI:10.2202/1540-8884.1085]

Governorate of Mamssani. (2007). Report of the outcome of the eighth islamic parliamentary election in the Mamasani constituency. (Persian)

Governorate of Mamssani. (2011). Report of the outcome of the ninth islamic parliamentary election in the Mamasani constituency. (Persian)

Governorate of Mamssani. (2015, 2016). Report of the outcome of the eighth islamic parliamentary election in the Mamasani constituency. (Persian)

Hafeznia, M. R., \& Kaviani Rad, M. (2014). Philosophy of political geography. Tehran: Research Institute of Strategic Studies. (Persian)

Heywood, A. (2016). Politics (A. Alem, Trans.). Tehran: Ney Publication. (Persian)

Huntington, S. (1991). The political system in the societies undergoes transformation (M. Salasi, Trans.). Tehran: Elm Publication. (Persian)

Jaafarinejad, M., Babanasab, H., \& Shahriar Rabiei, S. (2011). Analysis of the voting behaviour (case study: The tenth presidential elections in Haris election constituency). Political International Researches, 3(7), 159-208. (Persian)

Jones, M. (2007). An introduction to political geography: space, place and politics (Z. Pishgahifard \& R. Akbari, Trans.). Tehran: University of Tehran. (Persian)

Kaviani Rad, M. (2013). Election geography, with emphasis on presidential elections. Tehran: Kharazmi Publications. (Persian)

Kaviani Rad, M., \& Gharahbeygi, M. (2017). Election geography, fundations, concepts, methods. Tehran: Research Institute of Strategic Studies. (Persian)

Mirzaeitabar, M., Sadeghi, V., \& Hosseini, M. H. (2015). Explaining the relationship between political culture and economic development; Case study: Mamasani township. Political Science Quarterly, 11(22), 169208. (Persian)

Niakoui, A. (2014). Sociology of political disputes in Iran. Political Science Journal, 10(1), 199-230. (Persian)

Patti, C. (2006). Electoral geography for: Encyclopedia of human geography.

Political - Security Birth Certificate. (2011). Governorate of Nourabad Mamassani County. (Persian)

Rahnavard, F., \& Mahdavirad, N. (2010). Management of election. Tehran: Etelaat. (Persian)

Rumina, E., \& Sadeghi, V. (2015). Investigating the effect of tribalism on the voting pattern (case study: Mamsani county). Geopolitical Quarterly, 11(3), 84-116. (Persian)

Saedi, A. (2011). The principle of rural geography. Tehran: Samt. (Persian)

Statistical Center of Iran. (2006). Statistical Yearbook, National and provincial divisions. Retrieved from https://www.amar.org.ir. (Persian)

Statistical Center of Iran. (2011). Statistical Yearbook of Fars Province, Population statistics related to county of Fars province. Retrieved from http://stat.roostanet.com/details.php?id=1196. (Persian)

Veisi, H. (2016). Concepts and theories of political geography. Tehran: Samt. (Persian) 